
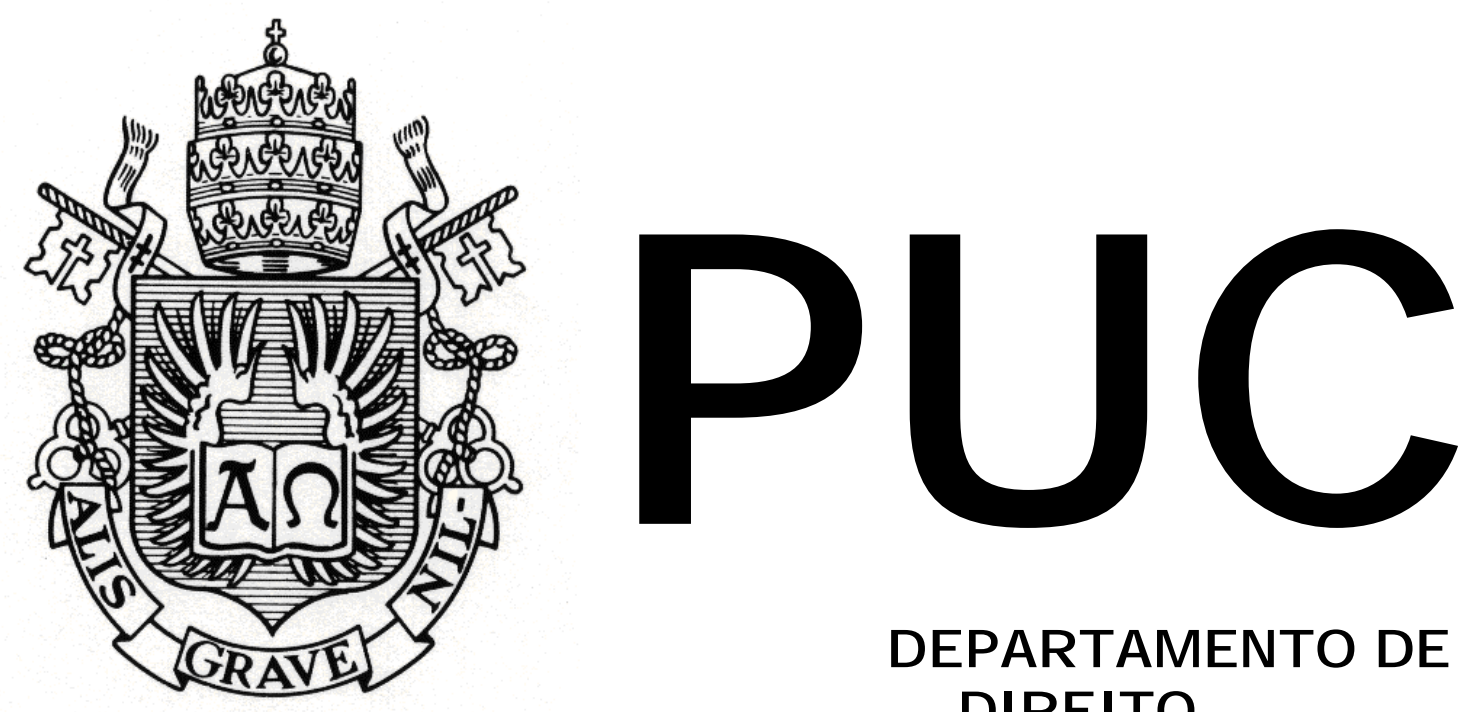

DEPARTAMENTO DE DIREITO

\title{
O PAPEL DOS PRECEDENTES NO NOVO CÓDIGO DE PROCESSO CIVIL
}

por

ISABEL MARTINS BARBOSA

ORIENTADOR: Fábio Carvalho Leite

2015.1

PONTIFÍCIA UNIVERSIDADE CATÓLICA DO RIO DE JANEIRO

RUA MARQUÊS DE SÃO VICENTE, 225 - CEP 22453-900

RIO DE JANEIRO - BRASIL 


\title{
O PAPEL DOS PRECEDENTES NO NOVO CÓDIGO DE PROCESSO CIVIL
}

\author{
por \\ Isabel Martins Barbosa
}

Monografia apresentada ao Departamento de Direito da Pontifícia Universidade Católica do Rio de Janeiro (PUC-Rio) para a obtenção do Título de Bacharel em Direito.

Orientador:

Fábio Carvalho Leite 


\section{Agradecimentos}

Ao professor Fábio Leite, meu orientador neste trabalho, pelas aulas tão bem ministradas, pelos anos de pesquisa conjunta e pela confiança que sempre depositou no meu trabalho.

A todos os membros do grupo "Ética e Realidade Atual" e, em especial, ao professor Noel Struchiner, por me abrir as portas da vida acadêmica e me mostrar a importância da interdisciplinaridade.

A todos com quem trabalhei no Ministério Público Federal e, em especial, à procuradora Aline Caixeta, pela disposição em explicar e ouvir, bem como pelo exemplo de compromisso com o cargo público.

Ao programa CEAL-Santander, por possibilitar meu intercâmbio acadêmico na Universidad Autónoma de Madrid, uma das vivências mais transformadoras da minha vida.

À Anna Lu Machado, ao Felipe Diniz, ao Filipi Peclat, à Isabel Accioly, à Isabelle Nobre e à Julia Barbosa, por terem sido os melhores compañeros de piso que eu poderia imaginar e uma verdadeira família para mim em Madri.

Ao Carlos Ibarra, por todo o carinho e por não ter hesitado nem um segundo em dividir tantos momentos inesquecíveis comigo.

À Gabriela Brandão, à Giulia Travassos, ao João Paulo Felizardo, ao João Pedro Borgerth, à Marcelle Felix, à Priscilla Fujikawa e à Raíla Sousa, que, ao lado de tantos outros amigos que fiz no Colégio Santa Marcelina, sempre se fizeram indiscutivelmente presentes, provando-se amigos para toda a vida. 
Àquelas que foram os melhores presentes que ganhei em minha trajetória universitária, Betina Sanglard, Isabella Olivieri, Maria Laura Saback, Natália Winter e Paula Rabacov, pelas tantas alegrias que compartilhamos, pelas dificuldades que enfrentamos juntas e pelos debates de alto nível que me proporcionam.

Ao Alejandro Chacoff e à Fernanda Barreto, que somam diariamente à minha família sua enorme alegria.

Aos meus irmãos, Julia Barbosa e Leonardo Barbosa, meus grandes exemplos e melhores amigos, por todo o amor e companheirismo que me ofertam desde as minhas primeiras lembranças.

Aos meus pais, Alzira Barbosa e Valmir Barbosa, em quem tenho a sorte de poder me espelhar, pelo amor incondicional, pela presença constante e pelo interesse genuíno por tudo que me diga respeito.

Particularmente, à minha irmã, pela ajuda na formatação deste trabalho, e ao meu pai, pela leitura cuidadosa e enriquecedora. 


\section{Resumo e palavras-chave}

$\mathrm{O}$ presente trabalho pretende investigar o papel que os precedentes passarão a desempenhar no direito brasileiro a partir da entrada em vigor do novo Código de Processo Civil. Até o final, demonstrar-se-á que, embora a jurisprudência já viesse ganhando importância nas últimas décadas, o referido diploma promete conferir verdadeira centralidade à criação e aplicação de precedentes na operação do direito.

Para tanto, inicialmente o foco recairá sobre a inserção do Brasil no contexto do civil law e do common law, explicitando o papel ocupado pelos precedentes em cada um deles. Em seguida, buscar-se-á compreender em que reside a ideia dos precedentes e a problemática relacionada a eles. Por fim, analisar-se-ão as principais mudanças do novo Código de Processo Civil que dizem respeito ao tema.

Palavras-chave: direito processual civil, precedentes, precedente horizontal, precedente vertical, jurisprudência, súmula vinculante, súmula, decisão judicial, observância obrigatória, novo Código de Processo Civil, fundamentação, argumentação, ratio decidendi, tese jurídica, stare decisis, distinguishing, overruling. 


\section{Sumário}

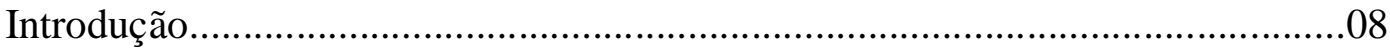

Capítulo I: Precedentes no civil law e no common law .......................................10

I.I Traçando distinções entre o civil law e o common law................................10

I.II A crescente aproximação entre o civil law e o common law.......................14

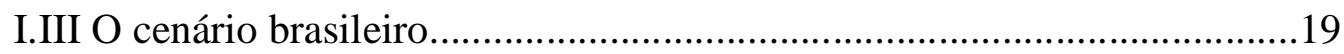

Capítulo II: A ideia e a problemática dos precedentes..........................................24

II.I Os modelos de tomada de decisão jurídica e as regras..............................24

II.II A conceituação dos precedentes............................................................27

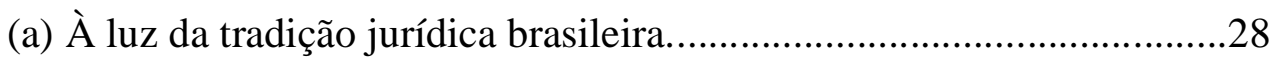

(b) À luz da tradição jurídica estadunidense.............................................31

II.III A problemática dos precedentes...............................................................33

II.IV A não aplicação dos precedentes.............................................................

Capítulo III: As inovações do novo Código de Processo Civil...............................41

III.I Precedente, jurisprudência e súmula.........................................................42

III.II Principais dispositivos legais pertinentes...............................................45

(a) Art. 927 do novo Código de Processo Civil...........................................46

(b) Art. 926 do novo Código de Processo Civil............................................51 
(c) Art. 489 do novo Código de Processo Civil......................................55

III.III O stare decisis como regra..........................................................58

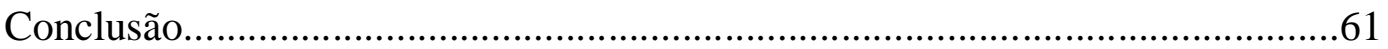

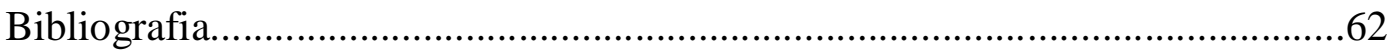




\section{Introdução}

No início deste ano de 2015, foi sancionado um novo Código de Processo Civil no Brasil. Sem dúvida alguma, trata-se de uma importantíssima inovação no direito brasileiro, que já está levando estudiosos e operadores do direito de volta às salas de aula. Embora se saiba que ele promoverá mudanças pontuais em inúmeros institutos jurídicos, espera-se que ele vá além: que concretize uma nova forma de conceber e operar o direito brasileiro - uma em que os precedentes sejam chamados a ocupar um lugar de verdadeiro destaque.

A introdução dos precedentes no novo Código de Processo Civil com essa envergadura deve ser entendida a partir do contexto de crescimento do papel da jurisprudência no direito brasileiro, bem como a partir dos

profundos debates que permearam a elaboração do referido diploma. Naquela época, muito já se dizia sobre o papel fundamental que os precedentes estavam aptos a desempenhar na busca pela unidade do direito, pela promoção da igualdade, pelo fortalecimento institucional, pela racionalidade econômica, etc.

Luiz Guilherme Marinoni chegou, inclusive, a sustentar que o novo Código de Processo Civil se justificaria pelo que chamou de "ética dos precedentes". O respeito aos precedentes seria uma maneira de preservar valores indispensáveis ao Estado de Direito, assim como de viabilizar um modo de viver em que o direito assumisse a sua devida dignidade, na medida em que, além de ser aplicado de modo igualitário, ele pudesse determinar condutas e gerar um modo de vida marcado pela responsabilidade pessoal (Marinoni, 2014, p. 15).

Como se vê, o novo Código de Processo Civil, por um lado, reflete o debate que já estava posto quando de sua elaboração e que lhe deu origem; por outro, o incendeia, tornando inevitável que os precedentes passem a ser objeto de estudos cada vez mais profundos e numerosos. Como coloca Fredie Didier Jr, "se é certo que o papel da jurisprudência é cada vez mais 
importante, também é certo que é preciso um estudo mais rigoroso da teoria do precedente e um aprimoramento na utilização das técnicas desenvolvidas a partir desse conjunto teórico" (Didier Jr et al, 2015, p. 490).

$\mathrm{O}$ presente trabalho busca dar uma pequena contribuição para as necessidades advindas desse cenário. Para tanto, de início abordará o papel tradicionalmente desempenhado pelos precedentes no civil law e no common law. Em seguida, estudará em que exatamente consiste a ideia dos precedentes e a problemática ligada à sua aplicação. Então, analisará as principais mudanças introduzidas pelo novo Código de Processo Civil concernentes ao tema, de forma a compreender a sua real dimensão.

Ao final, pretende-se que o leitor tenha percebido que aqueles que seguirem concebendo e operando o direito brasileiro sob uma lógica alheia à normatividade dos precedentes se tornarão, em breve, estranhos a ele. 


\section{Capítulo I}

\section{Precedentes no civil law e no common law}

A compreensão dos problemas ligados aos precedentes no Brasil - e dos desafios que se apresentam para o futuro - passa inevitavelmente por uma breve análise contextual. Embora tenha recebido influências tanto do civil law quanto do common law, conforme se verá mais adiante, o Brasil é entendido como um país de ordenamento jurídico romano-germânico e integra formalmente o primeiro grupo mencionado. Assim, faz-se necessário entender aquilo em que se pauta a distinção tradicionalmente feita entre o civil law e o common law, passando-se então à análise da dinâmica estabelecida entre eles para, em seguida, adentrar o estudo do cenário atual do direito brasileiro.

\section{I.I Traçando distinções entre o civil law e o common law}

Para compreender a distinção entre o civil law e o common law sob o prisma do papel dos precedentes no direito, cabe inseri-los nos contextos históricos em que se desenvolveram. Convencionalmente, entende-se que o civil law originou-se em Roma e foi se moldando a diversas influências ao longo do tempo, tais como a expansão e o declínio do Império Romano, as invasões bárbaras na Europa Ocidental, a consolidação do direito canônico, o florescimento das universidades e o movimento das codificações. Já o common law originou-se no direito inglês após a conquista normanda, desenvolveu-se consideravelmente na própria Inglaterra, perpassando a coexistência com o sistema jurídico da equity e a intensificação legislativa seguida às reformas democráticas, e ramificou-se nos países de colonização inglesa, ganhando contornos próprios especialmente relevantes para o Brasil nos Estados Unidos.

Ressalta-se que, embora normalmente se vislumbre o civil law e o common law primariamente como sistemas jurídicos, é pertinente a observação de Estefânia Barboza de que, às vezes, mais importa estudar as 
tradições legais do civil law e do common law do que propriamente esses sistemas em si (Barboza, 2014, p. 39). Citando John Henry Merryman e Rogelio Pérez-Perdomo, ela diz que tradições legais devem ser entendidas como atitudes sobre a natureza do direito historicamente enraizadas, sobre o papel do direito na política e na sociedade e sobre a organização e operacionalidade de um sistema legal, inserindo os sistemas jurídicos em uma perspectiva eminentemente cultural (Barboza, 2014, pp. 39-40). Destaca a autora que, enquanto cada país tem um sistema de direito próprio, falar em tradições jurídicas permite apontar características em comum de cada uma delas (Barboza, 2014, p. 39). Tal observação parece especialmente relevante para a temática a ser debatida neste trabalho, uma vez que as tradições legais tanto do civil law quanto do common law tiveram influência no Brasil.

Essa influência é importante principalmente no que tange à organização e operacionalidade do direito. Com base nesses aspectos, Víctor Ferreres e Juan Antonio Xiol traçam uma distinção pertinente entre o civil law e o common law. Eles entendem que, nos países em que vigora o primeiro, a estrutura judicial sempre se mostrou mais burocrática do que naqueles em que vigora o segundo. Associada à maior burocratização da estrutura judicial desses países estaria a sua maior hierarquização, tanto do ponto de vista orgânico quanto processual. Isso se refletiria na ascensão na carreira dos julgadores - em que seria relevante, em alguma medida, a opinião dos julgadores que ocupassem cargos superiores aos deles - e no sistema recursal desses países - relativamente amplos no que dissesse respeito à possibilidade de interposição de recursos, permitindo que os órgãos superiores reformassem com mais frequência decisões judiciais de órgãos inferiores (Ferreres \& Xiol, 2010, pp. 51-52).

Em contrapartida, para esses autores, os países em que vigora o segundo, o common law, sempre teve menos espaço a ideia de carreira judicial, de forma que os julgadores teriam se sentido menos pressionados a acatarem os posicionamentos defendidos pelos julgadores que ocupassem 
cargos superiores aos deles para que pudessem ascender profissionalmente com mais facilidade. Além disso, seriam relevantes as possibilidades recursais mais escassas desses países, com o acesso ao tribunal supremo caracterizando-se como algo verdadeiramente excepcional. Tudo isso dificultaria a uniformização da aplicação do direito, ensejando a necessidade de precedentes vinculantes para cumprir esse papel (Ferreres \& Xiol, 2010, pp. 52-53).

A conclusão que tiram disso é que, embora haja essas diferenças significativas entre ambos os sistemas - o civil law e o common law -, essas mesmas diferenças deixam à mostra um traço comum entre eles: o fato de que parece ser desejável que os tribunais inferiores ajustem seus entendimentos àqueles emanados pelos tribunais superiores a eles. Em uns, porém, não teria sido necessário oficializá-lo através dos precedentes vinculantes, dado que a sua estrutura orgânica e processual parecia garantir que isso fosse feito de modo suficiente. Já em outros teria sido preciso desenvolver essa ideia através da socialização da cultura jurídica dos precedentes, que teria passado a ocupar enorme espaço em sua estrutura judicial (Ferreres \& Xiol, pp. 53-54). Sob esse prisma, há que se perguntar se o fato de que a estrutura orgânica e processual dos países do civil law deixou de ser suficiente para lograr a uniformização do direito está relacionado ao crescimento do papel dos precedentes neles, conforme se verá adiante.

Ainda com relação à organização e operacionalidade do direito no civil law e no common law, cabe também a abordagem de alguns critérios utilizados por Patrícia Mello para concisamente pontuar diferenças entre ambos nesse sentido. São eles o protagonismo, o mecanismo lógico e o método interpretativo da manifestação do direito em cada tradição jurídica. Nas palavras da autora:

"A primazia conferida à jurisprudência, o raciocínio por indução e a metodologia de associação e distinção entre casos, adotados pelo common law, se oporiam, portanto, ao predomínio da lei, à dedução e ao método interpretativo do civil law, diferenciando os dois modelos." (Mello, 2008, pp. 12-13) 
Embora se faça, a princípio, uma análise em separado de cada um dos sistemas, a própria autora logo faz a ressalva de que o civil law e o common law não se desenvolveram de forma estanque e incomunicável, tendo se influenciado reciprocamente e encontrando-se atualmente em franco processo de aproximação.

A frase destacada sintetiza duas formas distintas de entender e manejar o direito (Mello, 2008, p. 12). No civil law, caberia à lei o protagonismo da manifestação do direito e às decisões judiciais o papel acessório e mediato de explicitar e declarar o significado do ordenamento positivo. A solução de demandas específicas seria obtida pelo mecanismo da subsunção, enquadrando-se casos concretos em regras gerais cujo significado seria revelado através da atividade interpretativa. No common law, caberia às decisões judiciais, detentoras de efeitos vinculantes e gerais, o protagonismo e à lei o papel secundário. A solução de demandas específicas levaria à formulação de regras a serem aplicadas em situações análogas pelo mecanismo da indução e, a partir daí, associações e distinções entre casos concretos ensejariam a aplicação de resultados idênticos ou a criação de novos precedentes, respectivamente.

Há alguns problemas nesse entendimento, a serem mencionados neste ponto apenas para ilustrar o dinamismo que normalmente escapa à análise convencional da questão. Com relação ao civil law, muito se discute sobre a suposta revelação do significado das regras gerais através de teorias interpretativas, em oposição à construção do mesmo a partir da interação com os intérpretes. Cuida-se da diferença entre os julgadores apenas extraírem das regras gerais significados preexistentes ou construírem-nos ativamente a partir de outros elementos, o que coloca em debate o próprio mecanismo de formação de decisões judiciais. São postas em questão, inclusive, as próprias categorias normalmente utilizadas para distinguir o civil law e o common law. Não seria mais difícil, por exemplo, falar no papel acessório das decisões judiciais no civil law se nelas também fosse construído o significado das regras gerais? E não estariam implicados 
também os precedentes, cujos próprios significados seriam recorrentemente construídos sob a análise de outros julgadores em casos concretos posteriores?

Com relação ao common law, os problemas não são mais escassos. Entendendo-se que a formulação de regras gerais partiria indutivamente da solução de demandas específicas, há que se perguntar o que exatamente seria generalizado: os fatos, o resultado, a ratio decidendi? Sendo a última, como extraí-la de uma decisão judicial? Além disso, outra questão relevante seria a de como identificar situações análogas que devessem ser confrontadas com a análise do precedente em questão, uma vez que parece pouco lógico e nada prático que todos os julgadores tenham que analisar todos os precedentes existentes para assegurar que os últimos não sejam relevantes no cálculo das decisões judiciais a serem tomadas. Essas questões são levantadas por Frederick Schauer e dizem respeito à própria natureza dos precedentes (Schauer, 2009, pp. 36-60). Embora alguns pontos problemáticos das definições convencionais do civil law e do common law tenham já sido brevemente expostos, considerações sobre a natureza dos precedentes têm profundas implicações neste trabalho e, portanto, foi-lhes reservado um capítulo próprio.

\section{I.Il A crescente aproximação entre o civil law e o common law}

A aproximação entre o civil law e o common law ocorreu devido a diversos fatores e foi sinalizada, dentre eles, também pelo crescimento da importância da jurisprudência ${ }^{1}$ como fonte do direito no civil law. Patrícia Mello destaca a variação das posições ocupadas por ela ao longo do tempo: de criativa e normativa no Estado pré-moderno, passando a declaratória e eminentemente esclarecedora do direito na modernidade, até uma atuação cada vez mais relevante na contemporaneidade, apesar de as decisões

\footnotetext{
${ }^{1}$ Há uma diferença terminológica entre precedentes e jurisprudência, que será explicitada no próximo capítulo, mas para os propósitos deste capítulo eles podem ser entendidos como equivalentes.
} 
judiciais não terem, em regra ${ }^{2}$, efeito vinculante nesse modelo (Mello, 2008, pp. 12-13).

Ao longo desse percurso, a função de interpretar e aplicar regras, especialmente nos períodos em que a legislação esteve em mais descompasso com a diversidade encontrada na realidade, acabou conferindo alguma centralidade às decisões judiciais. Seria o caso de codificações e consolidações ainda em vigor, a despeito do tempo decorrido desde a sua criação, como a Consolidação das Leis Trabalhistas no Brasil. É sabido por todos os que estudam e operam o direito trabalhista brasileiro que o mesmo é um direito eminentemente jurisprudencial, e que de nada adianta consultar a legislação sem atentar também para as inúmeras orientações jurisprudenciais e súmulas emanadas pelos tribunais.

A questão é que, como se verá adiante, as regras são necessariamente generalizações. E, quando se fala em generalizações, há um limite de tempo e de entendimento que inviabiliza a previsão de tudo que possa afetar o que for relevante para o direito, o que as torna atualmente ou potencialmente sobreinclusivas ou subinclusivas ${ }^{3}$, ainda que feitas minuciosamente. Isso se deve ao fato de que casos particulares não antecipados podem sempre surgir, mesmo quando se trabalhe com predicados factuais que sejam supostamente verdades universais. Trata-se de um descompasso sempre presente no direito - algumas vezes de forma mais evidente que outras -, dado que ele lida com generalizações cuja aplicação frequentemente pode ser posta em xeque (Struchiner, 2005, pp. 154-155).

A retomada e o desenvolvimento de teorias hermenêuticas que colocavam em relevo o papel das decisões judiciais também foram importantes para o crescimento do papel da jurisprudência no civil law. O já mencionado problema da declaração ou construção do significado das regras por parte de seus intérpretes é um exemplo das questões filosóficas

\footnotetext{
${ }^{2}$ Diz-se "em regra" porque, no Brasil, verifica-se uma tendência ao alargamento dessa vinculação, a exemplo da criação das súmulas vinculantes.

${ }^{3}$ Segundo Noel Struchiner, uma regra é sobreinclusiva quando englobam casos particulares que não geram a consequência que representa a justificação da regra, e subinclusiva quando deixam de tratar de certos casos que acarretam a consequência que representa a justificação da regra.
} 
que, por um lado, motivaram essas mudanças no campo interpretativo e, por outro, vieram cada vez mais à tona com elas. Patrícia Mello explica que essas teorias hermenêuticas defenderam uma análise dos litígios focada no problema, buscando sua composição a partir de diversos argumentos e pontos de vista suscitados pelas partes e de teoria persuasiva; observaram que o direito só se define à luz do caso concreto, por um processo circular que parte da precompreensão do texto, passa pelas particularidades da demanda, e retorna à regra, precisando seu conteúdo; pregaram que as pessoas não são governadas apenas por regras explícitas, mas também por princípios que decorrem dessas regras; e demonstraram, finalmente, que a atividade jurisdicional pressupõe que os magistrados formulem juízos de valor a partir dos fatos e argumentos apresentados pelas partes, legitimando-se assim a sua função criativa (Mello, 2008, pp. 49-50).

A autora situa esse processo no marco filosófico do pós-positivismo ${ }^{4}$ e destaca a centralidade nele desempenhada pelo direito constitucional, responsável por reaproximar o direito da moral e de considerações éticas e por conceber a ideia de um sistema axiológico aberto (Mello, 2008, pp. 5051). A Constituição estaria no vértice desse sistema, pensando-se na pirâmide normativa kelseniana, e, portanto, toda a sua base deveria ser interpretada de acordo com ela. É dessa supremacia, afirmada de modo paradigmático no julgamento do caso Marbury v. Madison pela Suprema Corte dos EUA, que decorre a necessidade do controle de constitucionalidade. Antes disso, porém, em "Os Federalistas", já se estabelecia que as limitações impostas pela Constituição ao Legislativo somente poderiam ser preservadas na prática por meio de Cortes de Justiça, as quais teriam o dever de "declarar nulos todos os atos contrários ao manifesto espírito da Constituição". Assim, estavam postos os alicerces para a supremacia da Constituição, hierarquicamente superior às demais

\footnotetext{
${ }^{4} \mathrm{O}$ paradigma do pós-positivismo é passível de críticas, especialmente no que concerne ao que se considera positivismo e à sua necessária superação na contemporaneidade. Sobre isso, cf. Struchiner, 2005.
} 
regras jurídicas do ordenamento positivo, e a consequente necessidade de um controle de constitucionalidade (Barboza, 2014, pp. 58-60).

Com relação à mencionada reaproximação entre direito e moral, cabe a colocação de que ela tem reaquecido debates de longa data, por vezes excessivamente dramatizados, sobre o jusnaturalismo e o juspositivismo. Uma vez que o constitucionalismo contemporâneo parece prescindir de teorias morais - na medida em que a Constituição passa a ser eminentemente axiológica e principiológica, a dispor de força normativa e a irradiá-la por todo o ordenamento jurídico, colocando-se como seu fundamento de validade e parâmetro interpretativo -, o debate parece girar não mais em torno da presença em si das teorias morais nos auditórios jurídicos, mas das perguntas que devem então ser feitas e do momento adequado para fazê-las. Noel Struchiner desenvolve essa questão e defende o positivismo conceitual ${ }^{5}$ enquanto importante opção metodológica, uma vez que ele é normativamente inerte e deixa as portas abertas para investigações adicionais sobre como lidar com o direito identificado como válido (Struchiner, 2005, pp. 52-54).

Quanto ao direito brasileiro e à apreciação de temas fortemente carregados de concepções morais pelo Judiciário, como as relativamente recentes e emblemáticas decisões do Supremo Tribunal Federal sobre união homoafetiva e interrupção de gravidez de fetos anencéfalos, Patrícia Mello os entende como um resgate de concepções de direito natural e de filosofia grega, centradas no debate de paradigmas de justiça e de razoabilidade e pautadas em abordagens tópicas e argumentativas (Mello, 2008, p. 51). A importância da argumentação para a construção de precedentes será aprofundada mais adiante, mas já se destaca que, sem ela, não se pode falar de um sistema de precedentes que efetivamente funcione e que possa ser levado a sério.

\footnotetext{
${ }^{5}$ Segundo Noel Struchiner, a tese do positivismo conceitual, segundo o qual o direito é identificado por meio de um critério de fonte e não um critério de mérito, é a única tese genuinamente compartilhada por todos os positivistas jurídicos. Sobre isso, cf. Struchiner, 2005, pp. 32-34.
} 
Além disso, a autora destaca que a ideia de preservação da força normativa da Constituição e o grande volume de casos levados a juízo ensejou a atribuição de efeitos gerais e vinculantes a algumas decisões sobre matéria constitucional e o reconhecimento de efeitos impositivos à jurisprudência consolidada em determinadas matérias (Mello, 2008, pp. 5152). Essas mudanças, apesar de centralizarem a jurisdição constitucional em menos órgãos judiciais - ou, no caso do Brasil, notadamente no Supremo Tribunal Federal -, também podem ser entendidas como uma flexibilização do civil law no sentido de buscarem adaptar a operacionalização do mesmo a problemas típicos da contemporaneidade, como a questão do aumento de judicialização de demandas que ocorre no Brasil, especialmente no período pós-Constituição de 1988. Buscou-se, em face a essas mudanças, conferir uniformidade e credibilidade aos julgados, limitar a discricionariedade dos julgadores e aprimorar a administração da justiça.

Por todo o exposto, foi possível verificar que, de fato, houve muitos pontos de intercâmbio entre o civil law e o common law ao longo de sua formação, resultando em uma aproximação entre eles que pode ser sintetizada em oito pontos principais, nem todos explorados neste tópico em função da maior relevância de destacar o movimento em si do que de destrinchar seus muitos vetores:

“1) O direito romano nasceu casuístico, problemático e concreto, apresentando semelhanças, em sua origem, com o common law.

2) A jurisdição do equity, responsável pela flexibilização e renovação do sistema inglês, se desenvolveu sob a inspiração de princípios do direito romano e do direito canônico.

3) O civil law tomou emprestadas do ordenamento britânico concepções pertinentes ao direito público, articulando, a partir delas, a harmonização entre o poder estatal e os direitos individuais.

4) Nos Estados Unidos da América, o common law original sofreu fortes adaptações, e virtude da influência da codificação, dentre outros fatores, disto resultando a elaboração de uma Constituição escrita, ou seja, de uma norma no estilo romano, à qual se atribuiu supremacia sobre todas as demais normas e eficácia apta a possibilitar ao Judiciário a declaração de invalidade das leis que conflitassem com ela.

5) A concepção de supremacia da Constituição desenvolvida em tal país inspirou-se na concepção de higher law do direito canônico.

6) Por outro lado, o constitucionalismo norte-americano teve grande influência sobre os países de direito codificado, tendo migrado com ele não 
apenas uma concepção de Constituição e de controle de constitucionalidade, mas, igualmente, alguns elementos inerentes ao sistema do common law.

7) Sob a influência de tais ideias, diversos países do civil law, a exemplo da Alemanha, da Itália e da Espanha, passaram a conferir efeitos obrigatórios e gerais às decisões de suas cortes constitucionais que reconhecessem a inconstitucionalidade de normas.

8) Por fim, o triunfo das ideias democráticas, as tendências estatais dirigistas, a necessidade de implementar mudanças sociais rápidas e de cumprir com compromissos internacionais têm provocado um crescimento de atividade legislativa em países que adotam o common law.” (Mello, 2008, pp. 53-54)

Trata-se de uma aproximação nitidamente sentida em diversos países do civil law, em maior ou menor amplitude: na Alemanha, com as decisões da Corte Constitucional Federal; na Itália, com os julgados da Corte Constituzionale; e na Espanha, em seu Tribunal Constitucional. No Brasil, isso também foi feito e, embora a importância das decisões judiciais fique mais evidente nas hipóteses em que lhes é conferido efeito geral e vinculante, ela também perpassa as demais decisões judiciais. Afinal, não podem os juízes analisar incidentalmente a constitucionalidade de uma regra em uma demanda com pedido diverso? Ainda que a decisão judicial produzida a partir dessa análise possua efeito inter partes, a sua importância não é considerável? Essas são questões pertinentes no que diz respeito à tomada de decisões judiciais e, portanto, à formação e à força dos precedentes no Brasil.

\section{I.III $O$ cenário brasileiro}

Conforme já se destacou, o Brasil recebeu influências tanto do civil law quanto do common law, tendo firmado sobre o primeiro as raízes herdadas de Portugal e abraçado o segundo pela construção de seu sistema de controle de constitucionalidade, profundamente influenciado pelo constitucionalismo estadunidense. Dessa forma, cabe uma breve explicação da estruturação do controle de constitucionalidade brasileiro.

Trata-se de um sistema híbrido, unindo o controle concreto-difuso sob influência estadunidense - e o controle abstrato-concentrado - sob influência europeia -, característica esta que conferiu ao Brasil uma 
experiência única no mundo e fez com que ele se deparasse com desafios igualmente únicos. É comum que estudiosos e operadores do direito entendam, de forma estática, os dois modelos que o compõem, sem dar a devida atenção ao crescente dinamismo entre eles e às implicações disso no papel dos precedentes do Brasil, a exemplo da criação da Ação Declaratória de Constitucionalidade e à modulação de efeitos em decisões judiciais em processos subjetivos.

Embora a jurisprudência já desempenhasse um considerável papel no direito brasileiro, foi sob a vigência da Constituição de 1988 que ela se desenvolveu robustamente. Isso é atribuído a vários fatores, comumente associados à redemocratização do país e à consequente amplitude de direitos e garantias individuais que se buscou consolidar depois do período de ditadura militar (Mello, 2008, pp. 56-57). Não bastando que o texto constitucional fosse principiológico por si só, ampliou-se também a sua pretensão normativa, implementou-se uma nova hermenêutica constitucional e inovou-se nos instrumentos de controle de constitucionalidade.

Assim, a Constituição de 1988 foi responsável por restaurar o Estado Democrático de Direito e por conduzir o retorno ao equilíbrio entre os Poderes da República, para o qual seria essencial que fosse fortalecida a autonomia e a independência do Judiciário. Tudo isso criou condições adequadas para o desenvolvimento judicial do direito e ajudou a promover a centralidade do direito constitucional no ordenamento jurídico, que, mais que um vértice da pirâmide normativa kelseniana, passou a ocupar a própria centralidade do mesmo, irradiando sua força normativa para todo ele. Nas palavras de Luís Roberto Barroso:

“A constitucionalização do Direito, por sua vez, está associada a um efeito expansivo das normas constitucionais, cujo conteúdo material e axiológico se irradia, com força normativa, por todo o sistema jurídico. Os valores, fins públicos e os comportamentos contemplados nos princípios e regras da Constituição passam a condicionar a validade e o sentido de todas as normas do direito infraconstitucional. Nesse ambiente, a Constituição passa a ser não apenas um sistema em si - com sua ordem, unidade e harmonia -, mas também um modo de olhar e interpretar todos os ramos do Direito. A constitucionalização do direito infraconstitucional não tem como sua principal marca a inclusão na Lei Maior de 
normas próprias de outros domínios, mas, sobretudo, a reinterpretação de seus institutos sob uma ótica constitucional." (Barroso, 2014)

Luís Roberto Barroso ressalta que a combinação da ampliação da força normativa da Constituição, claramente presente na autoaplicação do seu vasto leque de princípios, por exemplo, e a expansão da jurisdição constitucional foram responsáveis por conferir muito espaço à judicialização de muitos fatores da vida e, por conseguinte, também à crescente judicialização da política (Barroso, 2014). Com efeito, uma das marcas do cenário contemporâneo brasileiro tem sido um papel de destaque conferido ao Judiciário, especialmente - mas não exclusivamente - ao Supremo Tribunal Federal. Isso se deve, em grande parte, aos fatores acima elencados, embora também se possa falar em um esforço de centralização interpretativa desse órgão ${ }^{6}$. Cabe a ressalva de que, embora o foco comumente esteja no crescimento da importância da jurisprudência através dos precedentes vinculantes, é válido atentar que há reflexos também no âmbito dos precedentes não vinculantes.

Ocorre que, apesar de a alavancada da importância jurisprudencial ser reconhecida tanto entre estudiosos quanto operadores do direito, igual atenção não tem sido dada aos instrumentos necessários para conferir à jurisprudência a envergadura exigida por seu novo papel. Disso resulta um cenário esquizofrênico em que, de um lado, já se toma como assentada a ideia de que são argumentativamente vulneráveis as peças processuais que não apresentem jurisprudência favorável à causa defendida; e, de outro lado, procura-se essa mesma jurisprudência a partir de buscas superficiais e arbitrárias nos sites dos tribunais, raramente preocupadas com qualquer rigor metodológico ou com análises argumentativas minuciosas. Sequer se faz necessária uma observação mais detalhada para verificar as repercussões práticas dessa cultura jurídica: basta que se vá aos escritórios de direito - e lá, talvez, à sala dos estagiários. Na maior parte das vezes, o

\footnotetext{
${ }^{6}$ Um exemplo da referida centralização interpretativa é a adoção da teoria da transcendência dos motivos determinantes por alguns anos da década passada pelo Supremo Tribunal Federal, embora a mesma tenha sido abandonada por ele em 2007.
} 
que se verá é uma busca às cegas por ementas de decisões judiciais que contenham menções pertinentes à causa defendida, frequentemente descartando-se um número quase igual de decisões desfavoráveis a ela.

Mais que uma questão meramente institucional, trata-se de uma questão de cultura jurídica. Não se pode exigir dos julgadores mais rigor argumentativo nas decisões judiciais - e, consequentemente, nos precedentes formados a partir delas - sem exigir também dos demais operadores do direito o mesmo rigor, constituindo uma via de mão-dupla. A crescente importância da jurisprudência no Brasil tem-na colocado sob os holofotes e evidenciado a forma como é elaborada e utilizada. Fala-se muito do crescimento do recurso à argumentação no sistema jurídico instituído pela Constituição de 1988, mas fala-se pouco, por exemplo, de como alguns Ministros do STF, ao divergirem de seus colegas, não se preocupam em rebater os argumentos por eles utilizados, preocupando-se muito mais em fundamentar suas próprias decisões com outros argumentos ${ }^{7}$. Fala-se pouco, também, de como advogados muitas vezes lançam mão da jurisprudência para respaldar seus pleitos sem atentar para possíveis contradições entre a fundamentação do julgado utilizado e da sua própria ${ }^{8}$.

O novo Código de Processo Civil não foi - e nem poderia ter sido insensível a esse cenário. Ele se prontificou a propor soluções para alguns dos problemas que vêm sendo enfrentados no âmbito do Poder Judiciário brasileiro, especialmente no pós-Constituição de 1988. E o fez, em grande parte, através de significativas mudanças no papel dos precedentes no direito brasileiro. Pode-se dizer, assim, que o novo Código de Processo Civil em parte refletiu o movimento de aproximação que já vinha ocorrendo entre o civil law e o common law, dele bebendo, e em parte previu instrumentos que prometem intensificá-lo ainda mais.

\footnotetext{
${ }^{7}$ Há, no Judiciário brasileiro, um problema latente relativo ao excessivo volume de demandas judiciais. Este trabalho não é insensível a esse ponto, reconhecendo que o esforço argumentativo minucioso efetivamente exige tempo. O contraponto, porém, é que levar os precedentes mais a sério pode acabar sendo útil também a uma maior funcionalidade da operação do direito.

${ }^{8}$ Um exemplo corriqueiro seriam as ações indenizatórias por dano moral fundamentadas sobre as consequências e não as causas do mesmo, questão essa já debatida pelo Superior Tribunal de Justiça em um julgado muito citado nessas mesmas ações.
} 
Até agora, demonstrou-se qual tem sido o papel dos precedentes no Brasil até o momento. Ao longo deste trabalho, pretende-se demonstrar qual vai ser o papel dos precedentes no Brasil a partir da entrada em vigor do novo Código de Processo Civil. Em breve, não será mais possível entender o direito brasileiro a partir da mesma lógica que opera nos dias de hoje - o que está prestes a ocorrer é uma mudança estrutural na forma como ele é concebido e operado. Precisamente por isso, faz-se necessário, antes de mais nada, entender o funcionamento dos precedentes e os problemas envolvidos. 


\section{Capítulo II}

\section{A ideia e a problemática dos precedentes}

Devido ao papel central que os precedentes sempre ocuparam no common law, muito já se produziu sobre o tema nos países em que vigora tal tradição jurídica. Ainda que o civil law e o common law estruturem-se de maneiras distintas - embora estejam em franca aproximação, conforme demonstrado no capítulo anterior -, faz-se pertinente, além de analisar os precedentes a partir daquele contexto, fazê-lo também a partir deste, em que a problematização de sua prática já se encontra mais amadurecida. Assim, este capítulo pretende debruçar-se sobre o efetivo funcionamento dos precedentes no direito, objetivando compreender a lógica em que operam para mais bem dimensionar os desafios a serem enfrentados pelo direito brasileiro.

Para tanto, faz-se pertinente abordar alguns modelos de tomada de decisão jurídica. Essa abordagem visará, principalmente, diferenciar aqueles pautados em regras dos demais, apresentando as vantagens e desvantagens inerentes a eles. Com isso, busca-se compreender algumas das motivações para o fortalecimento do papel dos precedentes ${ }^{9}$ no direito brasileiro. Depois, pretende-se analisar a eficácia dos precedentes à luz da tradição jurídica brasileira para, em seguida, problematizá-la a partir da tradição jurídica estadunidense. Então, o foco recairá sobre a ideia por trás da normatividade dos precedentes e os problemas gerados por ela. Por fim, serão analisadas as hipóteses de não aplicação dos precedentes.

\section{II.I Os modelos de tomada de decisão jurídica e as regras}

Sabe-se que, no direito, há uma preocupação com outros fatores que não apenas a produção dos melhores resultados possíveis para cada caso

\footnotetext{
${ }^{9}$ Há uma problemática relativa ao conceito de precedentes que será mais bem explorada adiante. Até lá, porém, deve-se entendê-lo de forma necessariamente atrelada à normatividade.
} 
concreto. Não raro, doutrinadores e julgadores debruçam-se sobre a importância de também considerar, na tomada de decisões jurídicas, a credibilidade do Poder Judiciário, a celeridade da tutela jurisdicional, a preservação da segurança jurídica, entre outros fatores. Dependendo do peso atribuído a cada uma dessas preocupações, diferentes modelos de tomada de decisão jurídica mostrar-se-ão mais ou menos interessantes alguns mais preocupados em preservar o melhor resultado possível para cada caso concreto, outros em preservar o resultado apontado pelas regras aplicáveis, quando houver $\mathrm{um}^{10}$.

A escolha de um modelo de tomada de decisão jurídica que opte por preservar o melhor resultado possível para cada caso concreto permite aos julgadores incluir, em seus cálculos decisórios, todos os fatores que considerem relevantes para tanto. Justamente por isso, Noel Struchiner considera ilusório achar que a ideia de regra seja compatível com um modelo como esse. Regras que sejam afastáveis sempre que indicarem resultados contrários àqueles aos quais se chegaria por meio de outra análise - uma que considerasse todos os fatores entendidos como relevantes - não passam de meras sugestões. Isso faz com que a própria noção de regra fique perdida nesse contexto tomado por juízos "salomônicos" (Struchiner, 2005, pp. 160-161).

Diferentemente desse tipo de modelo de tomada de decisão jurídica, aqueles pautados em regras preveem intrinsecamente a produção de alguns resultados subótimos em relação à justificação das próprias regras. É dizer: ocasionalmente, o que se alcançará pela observância de uma regra não corresponderá ao resultado que ela pretendia produzir. Como coloca Frederick Schauer, citado por Noel Struchiner, "regras condenam o processo de tomada de decisões à mediocridade, exigindo a inacessibilidade da excelência" (Struchiner, 2005, p. 163). Diante disso, Noel Struchiner

\footnotetext{
${ }^{10}$ Os dois tipos de modelo de tomada de decisão jurídica de que se fala são retratados, respectivamente, pelo particularismo e pelo formalismo. Eles foram utilizados devido ao fato de representarem os extremos dos modelos de tomada de decisão jurídica. Para maiores considerações sobre o tema, cf. Struchiner, 2005, capítulo 9.
} 
questiona: por que optar por um modelo que exclua de antemão a possibilidade de se alcançar o melhor resultado para cada caso concreto? Por que entrincheirar regras, que são apenas generalizações prescritivas probabilísticas, necessariamente gerando uma determinada quantidade de resultados subótimos? (Struchiner, 2005, p. 163)

A resposta para essas perguntas geralmente está associada ao argumento de busca e preservação de previsibilidade, certeza e segurança jurídica, ao argumento de eficiência e ao argumento de alocação de poder (Struchiner, 2005, p. 164). Como os primeiros, ao menos para estudiosos do direito, parecem ser mais autoexplicativos que o último, a eles se destinarão algumas palavras. $\mathrm{O}$ argumento de alocação de poder abrange ao menos duas linhas de raciocínio: na primeira, deve-se entrincheirar as regras por razões prudenciais, acreditando-se que os tomadores de decisão cometeriam mais erros buscando as justificações subjacentes das regras do que adotando o resultado indicado por elas; na segunda, deve-se entrincheirar as regras por elas alocarem poder àqueles que realmente estão legitimados a decidir, ainda que suas decisões não sejam sempre corretas (Struchiner, 2005, pp. 164-167).

Com relação à primeira linha de raciocínio, um ponto deve ser destacado: não existe nenhum motivo para acreditar que um modelo de tomada de decisão jurídica seja melhor que outro para todas as esferas ou ambientes. Como exemplo, Noel Struchiner diz que possivelmente uma sociedade não queira que os policiais possam deliberar acerca das justificativas subjacentes às regras em cada momento de aplicação das mesmas, ou porque não teriam condições de entender as razões que explicam a sua existência, ou porque não teriam a isenção necessária para avaliá-las em função do cargo que ocupam (Struchiner, 2005, p. 165). Em suas palavras:

"O ponto é que a escolha por um ou outro modelo é contextual. A escolha por um modelo de regras, isto é, um modelo acontextual (que não avalia todos os aspectos do contexto, mas apenas os fatores previamente estabelecidos e destacados como relevantes pelas regras) é em si mesma uma escolha feita contextualmente e depende principalmente do grau de confiança que existe em 
relação aos responsáveis pela tomada de decisões. A escolha por um modelo de regras ou um modelo particularista também é contextual em outro sentido. Em última análise, a escolha por um modelo ou por outro depende daquilo que é considerado o bem maior ou o mal maior. Se é considerado que colocar obstáculos no caminho da decisão correta é o mal maior, então a melhor opção é a adoção de um modelo particularista. Se, ao contrário, acredita-se que o mal maior consiste na possibilidade de abusos e erros na avaliação das justificações, então o modelo mais adequado é o modelo formalista." (Struchiner, 2005, p. 165)

Se a escolha contextual de que trata esse trecho for por um modelo de tomada de decisões jurídicas pautado em regras - como o é o dos precedentes -, valorizar-se-ão a previsibilidade, a certeza, a segurança jurídica, a eficiência e a alocação de poder - todos fatores muito caros ao bom funcionamento do Poder Judiciário. Durante boa parte da tradição legal brasileira, tê-los em alta conta esteve associado apenas a uma preocupação com a preservação do resultado apontado pelas leis. Afinal, como já detalhado no capítulo anterior, o civil law caracteriza-se principalmente pela primazia das leis, o que fez com que, nessa tradição legal, a ideia de regras sempre estivesse muito associada a elas.

Entretanto, o crescente peso atribuído aos precedentes no civil law tem alargado esse enfoque, remetendo também a eles a ideia de regras. Cada vez mais, especialmente no Brasil, é preciso atentar para o fato de que as regras não provêm apenas das leis, mas também dos tribunais. Isso porque a ideia dos precedentes é que a solução de demandas específicas leve à formulação de regras a serem aplicadas, pelo mecanismo de indução, a situações análogas. Portanto, as considerações feitas até o momento mostram-se perfeitamente aplicáveis também aos precedentes, que são, em si mesmos, um modelo de tomada de decisão jurídica pautado em regras.

\section{II.II A conceituação dos precedentes}

Há um detalhe - que, na verdade, pouco tem de detalhe - que pode ter passado despercebido até aqui. Falou-se dos precedentes, de modo geral, atribuindo-lhes necessariamente o caráter de normatividade. Inclusive, apenas por isso - pelo fato de o entendimento que consagram dever ser seguido - foi possível entendê-los como um modelo de tomada de decisão 
jurídica pautado em regras. Realmente, como será exposto adiante, essa é uma maneira de entendê-los, especialmente quando se parte do contexto do common law, em que decisões judiciais são, em sua esmagadora maioria ${ }^{11}$, vinculantes. E, nos países do common law, é a essas decisões judiciais que costumeiramente dá-se o nome de precedentes, de modo que há uma identidade entre a ideia de precedentes e normatividade.

No Brasil, enquanto país inserido no contexto do civil law, sempre ocorreu o contrário: a esmagadora maioria das decisões judiciais, por muito tempo, não teve caráter vinculante. O movimento de aproximação entre o common law e o civil law, é verdade, já provocou algumas mudanças nesse cenário. Entretanto, talvez em razão da larga tradição jurídica brasileira noutro sentido, ocorra que não apenas as decisões judiciais vinculantes sejam entendidas como precedentes, mas também aquelas capazes de influir em futuras decisões judiciais, ainda que em outros graus. É dizer: aqui não necessariamente há uma identidade entre a ideia de precedentes e normatividade - assim como, por muito tempo, não necessariamente houve identidade entre a prática de precedentes e normatividade.

Para entender a abrangência com que os precedentes são costumeiramente entendidos no Brasil, bem como os graus de eficácia a eles atribuídos, vão-se analisar as categorias utilizadas por Patrícia Mello. Nas suas palavras, "perquirir acerca da eficácia dos precedentes significa buscar compreender a influência que eles exercem sobre a solução de casos análogos." (Mello, 2008, p. 64) Passa-se, agora, precisamente a essa tarefa.

\section{(a) À luz da tradição jurídica brasileira}

Os precedentes com eficácia normativa são aqueles que estabelecem um entendimento a ser obrigatoriamente seguido em casos análogos. Assim, os seus efeitos extrapolam o caso concreto em que se produziu a decisão

\footnotetext{
${ }^{11}$ Não se trabalha com a totalidade de decisões judiciais porque há casos em que elas não são, de fato, normativas. É o caso da decisão judicial de uma instância inferior em relação à decisão judicial de uma instância superior de sua jurisdição, por exemplo.
} 
judicial em questão, alcançando também uma amplitude incalculável de casos futuros. A razão de isso ocorrer é que esses precedentes geram regras e, com elas, comandos dotados de generalidade e aplicáveis permanentemente a todos os demais casos idênticos, sob pena de sanção. Para pessoas inseridas no contexto do civil law, trata-se de algo familiar, mas normalmente associado às leis. É comum que não se atribua a mesma importância aos precedentes - e exatamente por isso é importante lembrar que aqueles com eficácia normativa geram regras, à imagem e semelhança das leis.

É importante, ainda, notar que Patrícia Mello entende os precedentes com eficácia normativa como uma exceção nos países do civil law, manifestando-se principalmente em decisões proferidas pelos tribunais constitucionais - tem sido esse o caso do Brasil. Já nos países do common law, essa seria a regra, notadamente porque as decisões produzidas pelas cortes superiores constituem precedentes normativos para as cortes inferiores de uma mesma jurisdição (Mello, 2008, p. 64). No entanto, faz-se a ressalva de que as considerações da autora são anteriores ao novo Código de Processo Civil no Brasil, que trouxe significativas mudanças ao direito brasileiro no que concerne a esse tema.

Os precedentes com eficácia impositiva intermediária são aqueles que, embora não estabeleçam um entendimento a ser obrigatoriamente seguido em casos análogos, fazem com que as decisões em outro sentido sejam profundamente criticadas e provavelmente revistas. Patrícia Mello diz que há situações em que não se atribui eficácia normativa às decisões judiciais, mas lhes são reconhecidos outros efeitos impositivos mais brandos, para além do processo, como a possibilidade de fundamentação mais rarefeita no que respeita ao direito aplicável, quando forem invocadas, e de facilidades recursais, quando forem contrariadas. A própria autora entende ser essa uma categoria residual, utilizada para as hipóteses em que não se pode caracterizar uma decisão judicial como normativa, mas em que 
tampouco se pode qualificá-la como meramente persuasiva - a próxima categoria a ser analisada (Mello, 2008, pp. 62-66).

Nos países do civil law, essa categoria é muito comum. Quando se fala de jurisprudência dominante sobre determinada matéria, é de precedentes intermediários que se está falando. Nessa situação, acaba-se reconhecendo maior força impositiva ao entendimento consagrado nos tribunais, tanto em virtude do grau de estabilidade alcançado por ele, quanto pela necessidade de promover a uniformização das decisões judiciais. Nos países do common law, embora a regra sejam os precedentes normativos, precedentes intermediários também são significativos. Os precedentes produziriam efeitos intermediários quando sua utilização se desse pelo próprio órgão que os proferiu. Isso porque as cortes devem respeitar seus próprios precedentes, mas podem, fundamentando adequadamente a decisão, eventualmente superá-los.

Os precedentes com eficácia meramente persuasiva, por fim, estão presentes sempre que se invoca determinado julgado apenas para fins de persuasão do magistrado, não sendo possível atá-lo a seus termos. Trata-se das decisões judiciais que podem influir na formação da convicção dos juízes, fornecer elementos para a argumentação das partes e reforçar a motivação das sentenças. Como Patrícia Mello destaca, porém, é importante notar que, na medida em que um precedente meramente persuasivo se repete, ele dá ensejo à formação de uma jurisprudência dominante sobre determinado assunto e passa a agregar efeitos impositivos mais ou menos brandos ao entendimento nele consolidado (Mello, 2008, p. 66). Assim, embora a eficácia dos precedentes meramente persuasivos seja menor que a dos demais tipos de precedente, seu potencial é considerável.

Eles são a regra nos países do civil law, mas também podem ser encontrados nos países do common law, como no caso de decisões judiciais de primeira instância, entendimentos consagrados por órgãos inferiores quando invocados por órgãos superiores e julgados de outras jurisdições. 
Dentre os atributos diferenciadores utilizados por Patrícia Mello em seu esforço de categorização, um será especialmente relevante para o desenvolvimento deste trabalho: a normatividade. Tal relevância se justifica pelas alterações promovidas pelo novo Código de Processo Civil no direito brasileiro para conferir normatividade ao entendimento preconizado por muitas decisões judiciais com relação às decisões judiciais futuras, conforme será trabalhado no próximo capítulo. Assim, aquilo que sempre foi característico dos países do common law passará a ser comum também no direito brasileiro, motivo pelo qual faz-se pertinente analisar especificamente como funciona a normatividade dos precedentes.

\section{(b) À luz da tradição jurídica estadunidense}

Essa análise recorrerá ao estudo desenvolvido por Frederick Schauer no capítulo de uma de suas obras intitulado "A Prática e a Problemática dos Precedentes" $" 12$, em que ele aborda essa temática no contexto dos Estados Unidos. Antes, porém, voltando à menção que foi feita sobre as diferentes formas de se entender o conceito de precedentes - especialmente quando considerada a diferença contextual entre o common law e o civil law-, cabe detalhar essa questão na figura dos dois autores que embasam a investigação aqui empreendida: Patrícia Mello, já analisada, e Frederick Schauer.

Patrícia Mello parece entender os precedentes como decisões judiciais que os julgadores possam considerar, em maior ou menor grau, ao tomarem suas próprias decisões judiciais - da normatividade, em que eles passam a dever considerá-las, à mera persuasão. É a partir desses diferentes graus que ela os classifica segundo a sua eficácia. Já Frederick Schauer parece entendê-los como decisões judiciais que os julgadores necessariamente devam considerar ao tomar suas próprias decisões judiciais, ainda que contrariamente ao seu melhor juízo (Schauer, 2009, pp.

\footnotetext{
${ }^{12}$ Em tradução livre de Fábio Shecaira, Noel Struchiner e Diego Werneck, bem como todos os demais trechos deste capítulo que serão mencionados no decorrer deste trabalho.
} 
37-38). Ou seja, o próprio conceito de precedentes, para ele, estaria atrelado à normatividade - o que, diferentemente do conceito utilizado por Patrícia Mello, excluiria a ideia de mera persuasão, dado que tal ideia implica a adoção de um determinado entendimento não pela obrigação de fazê-lo, mas pelo genuíno convencimento do julgador (Schauer, 2009, p. 38).

Frederick Schauer divide os precedentes em horizontais e verticais. Trata-se de uma diferenciação pensada a partir da relação estabelecida entre o órgão que profere o precedente e o que deve segui-lo, ainda que essa diferenciação acabe tendo implicações relevantes também quanto à eficácia. Os precedentes verticais relacionam-se à ideia de que se espera que órgãos inferiores sigam as decisões judiciais tomadas por órgãos superiores de sua jurisdição. Fala-se, portanto, de uma relação manifestada em uma hierarquia institucional - por isso, vertical. Já os precedentes horizontais relacionam-se à ideia de que se espera que os órgãos sigam as suas próprias decisões anteriores. É a chamada doutrina do stare decisis. Nesse caso, a relação se manifesta no lapso temporal entre o mesmo órgão no passado e no presente - por essa razão, horizontal (Schauer, 2009, pp. 36-37). Isso faz com que, para Schauer, existam precedentes nessas duas direções.

Entende-se que os precedentes verticais são absolutamente vinculantes, de forma que o órgão inferior não tenha escolha senão obedecer a um precedente do órgão superior (Schauer, 2009, p. 57). E entende-se que os precedentes horizontais são relativamente vinculantes, de forma que eles possam ser muito ocasionalmente revistos, no que tange ao entendimento por eles projetado, quando se constata que foi cometido um erro no passado que extrapole totalmente o alcance dos erros normais, seja no seu tamanho, seja na gravidade das suas consequências (Schauer, 2009, p. 60).

Note-se que Patrícia Mello insere os precedentes horizontais - ainda que não tenha se referido a eles dessa forma - na categoria da eficácia impositiva intermediária e não na eficácia normativa, por entendê-los não como dotados de normatividade e sim de efeitos impositivos mais brandos. 
Frederick Schauer, por sua vez, como decorre do simples fato de preliminarmente tê-los entendido como precedentes, enxerga-os como dotados de alguma normatividade, ainda que relativa e não absoluta. Para ele, o ponto central da prática dos precedentes horizontais é justamente que os órgãos devem tratar suas decisões judiciais anteriores como vinculantes tão somente pelo fato de elas existirem e não por entenderem-nas como corretas, o que imporia um ônus argumentativo bastante alto à sua revisão (Schauer, 2009, pp. 59-60).

Assim, deve-se atentar para o fato de que as considerações de Frederick Schauer sobre normatividade cabem tanto em relação aos precedentes que Patrícia Mello entende como dotados de eficácia normativa - que abrangeriam os precedentes verticais - quanto aos que ela entende como dotados de eficácia impositiva intermediária - que abrangeriam os precedentes horizontais. Daqui em diante, o olhar mais utilizado será o de Frederick Schauer. Isso se dará por dois motivos: primeiramente, porque é a partir de suas considerações que se vai estudar o funcionamento e a problemática dos precedentes; em segundo lugar, porque o novo Código de Processo Civil introduz a identidade entre a ideia de precedentes e de normatividade, há pouco referida como sendo característica do common law.

\section{II.III A problemática dos precedentes}

As considerações conceituais que acabam de ser feitas são relevantes principalmente na medida em que ajudam na construção de um debate em que todos falem a mesma língua, mas, fossem quais fossem as opções terminológicas adotadas, alguns problemas práticos teriam que ser enfrentados. Notadamente, com relação a cada caso concreto submetido ao Poder Judiciário, será necessário identificar os precedentes a serem considerados e as regras decisórias expressas por eles. Ou seja, aceitando-se a ideia de que os órgãos do Poder Judiciário devem seguir as decisões judiciais passadas - sejam elas de órgãos superiores, sejam elas as suas 
próprias -, virão as seguintes perguntas: o que conta como uma decisão judicial passada que deve ser observada? Que regra decisória essa decisão judicial passada expressa (Schauer, 2009, pp. 44-45)? Trata-se de dois parâmetros inter-relacionados em torno dos quais gira a problemática dos precedentes.

Às vezes, responder a essas perguntas é a uma tarefa simples e direta - por exemplo, parece óbvio que um caso envolvendo a constitucionalidade da política de cotas étnico-raciais na Universidade Federal do Rio de Janeiro teria como precedente a ADPF 186, em que o Supremo Tribunal Federal considerou constitucional a política de cotas étnico-raciais para a seleção de estudantes da Universidade de Brasília. Parece óbvio, também, que a regra decisória extraída dele é que tais medidas não ofendem o princípio constitucional da igualdade. Como destaca Frederick Schauer, na maior parte das vezes, porém, não se chega nem perto desse nível de clareza quanto a quais decisões judiciais passadas devem ser observadas e quanto às regras decisórias expressas por elas (Schauer, 2009, p. 44).

A razão principal para essa dificuldade é o fato de que dois casos nunca são exatamente iguais - eles têm peculiaridades com relação ao tempo, ao lugar e às circunstâncias em que ocorrem. Às vezes, essas peculiaridades em nada influem na identificação das decisões judiciais passadas que devem ser observadas, nem na regra decisória expressa por elas. Há casos judicializados de direito marítimo, por exemplo, em que as únicas diferenças, de um caso para o outro, dizem respeito ao nome dos navios envolvidos e ao ano em que ocorreu o fato que ensejou a controvérsia. No entanto, há outras situações em que as diferenças em jogo são muito mais substanciais, o que tem implicações consideráveis. Nas palavras de Frederick Schauer:

"Quando isso ocorre, surgem dois problemas inter-relacionados. O primeiro diz respeito à identificação inicial do precedente relevante. Há alguma decisão anterior que mereça ser tratada como caso precedente? O segundo envolve definir o significado desse caso precedente para a decisão do caso atual. Em um mundo no qual não há identidade completa entre dois ou mais casos ou eventos, essas tarefas envolvem determinar se há similaridade relevante entre um dado caso precedente possível e o caso atual, pois somente quando a resposta for 
afirmativa é que o tribunal atual estará obrigado a seguir o que o tribunal precedente dispôs." ${ }^{, 13}$ (Schauer, 2009, p. 45)

O grande problema é determinar o que o autor chama de similaridade relevante, ou seja, o ponto a partir do qual uma dada similaridade entre dois casos passa a ser suficientemente importante para que a decisão judicial proferida no primeiro caso deva ser observada no segundo.

Como exemplo, ele cita um caso em que se decidiu que uma companhia fabricante de carros seria responsável, perante o comprador de um de seus carros, pelos danos causados por rodas defeituosas fabricadas por outra companhia - mas incorporadas pela companhia fabricante de carros em seus produtos -, ainda que o comprador em questão tivesse fechado o negócio com um intermediário. Note-se que, nesse caso, não havia liame contratual entre o comprador de carros e a companhia fabricante de carros, mas isso não impediu que ela fosse responsabilizada pelo defeito da roda, uma vez que poderia tê-lo detectado antes de incorporá-la ao produto. $\mathrm{O}$ autor destaca que, se um novo caso dissesse respeito a outra companhia fabricante de carros ou a outras partes defeituosas que não rodas, provavelmente haveria poucas dúvidas quanto à relevância de sua similaridade com o primeiro caso.

Mas e se o novo caso dissesse respeito a uma mulher que estivesse tomando uma cerveja de garrafa opaca em um café e, ao reencher seu copo, visse um animal decomposto sair da garrafa? Nesse caso, a mulher processou a companhia fabricante de cervejas, ainda que tampouco houvesse liame contratual entre ela e a referida companhia. Se ele tivesse surgido na mesma jurisdição do caso anterior - e em uma instância igual ou inferior à que o houvesse julgado -, essa mulher certamente teria argumentado que, no passado, já se havia dispensado o liame contratual em

\footnotetext{
${ }^{13}$ No original: "When that happens, two interrelated problems arise. The first is the initial identification of the relevant precedent. Is some previous decision to be treated as a precedent case at all? The second problem is the determination of what that precedent case will now be taken to stand for. In a world in which there is no complete identity between any two cases or any two events, these tasks involve determining whether there is a relevant similarity between some possible precedent case and the instant case, for only when there is will the instant court be under an obligation to follow what the precedent court has held."
} 
situações de consumo. Já a companhia fabricante de cervejas teria argumentado que o caso anterior não havia entendido o liame contratual como desnecessário em casos que não envolvessem maquinários perigosos, como automóveis. Diante dessas duas posições em conflito, como o órgão responsável por julgar o segundo caso faria para decidir se o primeiro caso deveria ou não ser observado no julgamento do segundo e, se sim, o que estaria disposto nele (Schauer, 2009, pp. 45-46)?

Frequentemente, busca-se essa resposta na chamada ratio decidendi da decisão judicial anterior - ou seja, no seu fundamento ou razão. $\mathrm{O}$ foco passaria a estar não mais no que foi decidido em si, mas no porquê dessa decisão (Schauer, 2009, p. 50). Entende-se que, assim como as leis, as decisões judiciais têm razões subjacentes a elas. Ocorre que, diferentemente das leis, nos precedentes as regras não estão expressas - é preciso extraí-las, generalizando, assim, o que há de mais relevante neles, a razão por trás da decisão tomada. É, pois, em função dessa necessidade que passa a ser importante falar da ratio decidendi, entendendo-se que, sem ela, faria pouco ou nenhum sentido atribuir normatividade aos precedentes. A partir disso, Frederick Schauer chama atenção para mais um problema: como fazer, então, para saber qual foi a ratio decidendi?

Houve um considerável esforço argumentativo para sustentar que a ratio decidendi poderia ser encontrada nos próprios fatos do precedente, conforme descritos pelo órgão que o julgou, em conjunto com o seu resultado. Como ressalta Frederick Schauer, Arthur Goodhart contribuiu para isso, mas, para o primeiro, há alguns problemas na visão do segundo. Buscando nesses elementos a ratio decidendi, não se saberia em que nível de generalidade compreender os fatos em questão (Schauer, 2009, p. 51). E, mesmo que se falasse em fatos relevantes e não apenas em fatos, embora o problema da generalização fosse mitigado, surgiria o problema de que essa relevância seria, ela mesma, determinada pelo direito, já que um fato passaria a ser relevante apenas quando uma regra jurídica o tornasse juridicamente importante. E, como coloca Frederick Schauer, "se o critério 
para definir a relevância vem de fora do caso precedente - de uma lei, por exemplo -, então é a lei que está fazendo todo o trabalho, e isso não seria de modo algum uma situação de vinculação a precedentes." (Schauer, 2009, p. 52)

Volta-se, portanto, à questão de como definir a ratio decidendi. Frederick Schauer procura uma resposta nas próprias decisões judiciais que funcionariam como precedentes, notando que, além dos fatos e do resultado, a grande maioria delas se preocupa em dizer por que chegou àquela conclusão específica. Assim, a grande questão passaria a ser que os próprios órgãos judiciais dissessem qual é a ratio decidendi de suas decisões. Às vezes, eles de fato fazem isso, anunciando em sua própria decisão a regra expressa no caso. Mesmo quando isso não ocorre, porém, Frederick Schauer mantém que são as próprias palavras utilizadas na decisão judicial que devem indicar o caminho a ser seguido. Ainda que elas não sejam expressas quanto ao porquê de se ter chegado a determinado resultado, as categorizações feitas por ela - por exemplo, referir-se a alguém pelo nome, como policial ou como agente público - frequentemente indicam a ratio decidendi do caso em questão (Schauer, 2009, pp. 52-54).

$\mathrm{E}$, assim, seria ao que efetivamente disse o órgão judicial que as pessoas deveriam se ater na busca pela ratio decidendi, para identificarem os casos em que os precedentes devam ser considerados, bem como as regras decisórias neles contidas. Obviamente, isso reforça ainda mais o dever dos julgadores de fundamentarem suas decisões, uma vez que a aplicação dos precedentes dependerá substancialmente da qualidade da argumentação por eles desenvolvida.

\section{II.IV A não aplicação dos precedentes}

Os problemas tratados acima decorrem da aplicação dos precedentes e, por isso, são especialmente importantes quando considerados sob a ótica de que os precedentes efetivamente devem ser aplicados. É fundamental perceber, contudo, que só faz sentido falar na observância obrigatória dos 
precedentes com relação aos casos aos quais eles de fato forem aplicáveis, por mais óbvio que isso possa soar.

Pode ser, por exemplo, que um julgador realmente encare os precedentes com seriedade, mas opte por não seguir o entendimento preconizado por um deles por entender que circunstâncias fáticas que the estão postas para análise são peculiares o suficiente para afastar a sua vinculação ao precedente em questão. Em uma linha um pouco diferente, pode ser que um julgador que nutra igual respeito pelos precedentes entenda que, de fato, trata-se de hipótese de aplicação de determinado precedente, mas opte por afastá-lo por achar que o entendimento preconizado por ele não mais se justifica, ressalvando a necessidade de que isso seja feito apenas em caráter excepcionalíssimo e com uma fundamentação consistente.

Esses dois exemplos retratam dois métodos de não aplicação de precedentes: distinguishing e overruling. Trata-se dos métodos mais relevantes para o escopo deste trabalho, porque, como se verá adiante, o novo Código de Processo Civil faz referência a eles em um de seus dispositivos. Por isso, a eles será dada uma atenção maior que a outros métodos de não aplicação de precedentes.

A plena compreensão do distinguishing exige a lembrança da noção de que a aplicação de um precedente parece depender da identificação da sua ratio decidendi. Isso porque o distinguishing revela a demonstração das diferenças fáticas entre os casos ou a demonstração de que a ratio do precedente não se amolda ao caso sob julgamento, uma vez que os fatos de um e outro são diversos. Assim, ele exige, como antecedente lógico, a identificação da ratio decidendi do precedente. Note-se que o distinguishing não significa sinal aberto para que o julgador desobedeça aos precedentes que não lhe convêm, uma vez que diferenças fáticas, por si só, nem sempre são suficientes para se concluir pela inaplicabilidade de precedentes. É essencial a argumentação de que tal diferença é material, ou seja, de que ela 
se funda em fatos fundamentais - e, portanto, relevantes - de ambos os casos (Marinoni, 2010, pp. 326-327).

$\mathrm{O}$ overruling, diferentemente do distinguishing, coloca em xeque a corretude do precedente, de forma que a discussão deixa de estar meramente no campo da sua aplicabilidade. Fala-se da possibilidade de o julgador revogar seus próprios precedentes com base em certos critérios, que Luiz Guilherme Marinoni, citando Melvin Eisenberg, diz serem a não correspondência a padrões de congruência social e consistência sistêmica, somada ao fato de os valores basilares da estabilidade - basicamente, a isonomia, a confiança justificada e a vedação da surpresa injusta - passarem a fundamentar mais a revogação que a preservação dos precedentes (Marinoni, 2010, p. 390) ${ }^{14}$. Importante destacar que, para Luiz Guilherme Marinoni, assim como Frederick Schauer, a possibilidade de revogação de precedentes não é excludente da observância obrigatória de um órgão às suas próprias decisões. Tal obrigatoriedade continuaria existindo, apenas implicando a exigência de que a revogação estivesse submetida a determinados critérios (Marinoni, 2010, pp. 389-390). Em suas palavras:

"Portanto, se é certo que o sistema de precedentes que não admite o overruling não tem mais lugar, uma vez que impede o desenvolvimento do direito, também não há como pensar que a possibilidade de revogar precedentes é excludente da eficácia horizontal dos precedentes ou da obrigatoriedade de respeito às próprias decisões. Não há sistema de precedentes quando as Cortes Superiores não se submetem a critérios especiais para revogar os seus precedentes. E é exatamente esta submissão a critérios que caracteriza a eficácia horizontal no direito contemporâneo." (Marinoni, 2010, pp. 389-390)

As demais formas de não aplicação de precedentes são menos conhecidas que o distinguishing e o overruling. Pode-se falar em overriding, que ocorre quando um órgão limita o âmbito da incidência do precedente devido à superveniência de uma norma legal ou de um entendimento posteriormente formado, levando à superação parcial do entendimento. Já o transformation seria o chamado overruling implícito, ou seja, quando se abandona uma posição anterior sem expressa substituição

\footnotetext{
${ }^{14}$ Esse critério é aprofundado em Marinoni, 2010, pp. 390-402 e certamente se sujeita a críticas. Para o presente trabalho, porém, mais importa entender que o overruling deve ocorrer apenas em caráter excepcionalíssimo e com uma fundamentação consistente do que aprofundar tal critério.
} 
por uma subsequente. Cabe lembrar que, no direito brasileiro, não se admite a ocorrência desse fenômeno (Didier Jr. et al, 2015, p. 494). Há ainda o technique of signaling, que é quase um meio-termo entre o distinguishing e o overruling. Por meio dela, identifica-se que o conteúdo de um precedente é equivocado, mas, em nome da segurança jurídica, deixa-se de revogá-lo naquele momento, apenas evidenciando a sua perda de consistência e sinalizando a sua provável e futura revogação. Por fỉm, há a chamada decisão per incuriam, caso em que, para a validade do julgado, é necessário que o julgador demonstre que, ainda que tivesse analisado a lei ou o precedente ignorado, o resultado a que chegaria seria o mesmo (Redondo, 2014, pp. 14-16). 


\section{Capítulo III}

\section{As inovações do novo Código de Processo Civil}

É sabido que o novo Código de Processo Civil promoveu várias alterações no direito brasileiro, notadamente com relação ao tratamento conferido aos precedentes. Para Luiz Guilherme Marinoni et al, a percepção de que o texto legislativo não se confunde com a norma - sendo esta não o objeto, mas o resultado da interpretação - abriu espaço para que se pensasse na decisão judicial não só como um meio de solução de determinado caso concreto, mas também como um meio para promoção da unidade do direito (Marinoni et al, 2015, p. 606). Isso porque, ao decidir um caso, o julgador necessariamente cria duas normas jurídicas: uma de caráter geral, fruto de sua interpretação dos fatos envolvidos na causa e de sua conformação ao direito positivo; e uma de caráter individual, que constitui a decisão daquela situação específica que lhe foi posta para análise (Didier Jr. et al, 2015, p. 442).

Existindo as normas apenas a partir da interpretação, pode-se dizer que o princípio da legalidade significa, na verdade, respeito à interpretação conferida à lei pelos órgãos institucionalmente de tanto encarregados ${ }^{15}$. Assim, quem quer que se preocupe em saber o espaço de liberdade de ação dos julgadores e em garantir a igualdade de todos perante a ordem jurídica, bem como em firmar a segurança jurídica como fundação da interpretação e aplicação do direito, obviamente não pode virar as costas para o problema da interpretação judicial do direito e dos precedentes daí oriundos. Do contrário, corre o risco de se ver nas mãos de um direito que não respeita a liberdade, a igualdade e a necessidade de segurança no tráfego jurídico (Marinoni et al, 2015, pp. 606-607). Atento a isso, o novo Código de Processo Civil preocupou-se mais que seu antecessor com o papel dos precedentes, inovando a esse respeito no direito brasileiro.

\footnotetext{
${ }^{15}$ Conforme será referenciado a seguir, este entendimento é o de Luiz Guilherme Marinoni et al. Fredie Didier Jr. et al, por sua vez, entendem que os precedentes também compõem o direito - ao lado, por exemplo, da lei - e são, portanto, englobados pelo princípio da legalidade. Note-se que há uma diferença sutil entre ambos os entendimentos, na medida em que, para Luiz Guilherme Marinoni et al, sequer há como se falar em respeito à própria lei sem passar pelo respeito à interpretação jurídica que lhe conferem os órgãos institucionais a tanto encarregados.
} 
Para analisar em que consiste essa inovação, será preciso, antes, destrinchar os conceitos de precedentes, jurisprudência e súmula. Em seguida, serão analisados os dispositivos legais do novo Código de Processo Civil que dizem respeito ao tema, abordando, notadamente, a ampliação do rol de precedentes obrigatórios - ou, aqui, apenas precedentes -, os deveres gerais a que passam a submeter-se os tribunais e as inovações do referido diploma no que tange à fundamentação. Por fim, pretende-se que reste clara a importância primordial da fundamentação cuidadosa das decisões judiciais, necessária à concretização dos objetivos perseguidos pelo novo Código de Processo Civil e ao atendimento dos anseios da Constituição de 1988.

\section{III.I Precedente, jurisprudência e súmula}

De início, cabe definir alguns conceitos repetidamente empregados pelo novo Código de Processo Civil, quais sejam de precedente, jurisprudência e súmula. Para Fredie Didider Jr. et al, trata-se de noções distintas, embora umbilicalmente ligadas. Um precedente, conforme já visto, surge a partir da intepretação das leis à luz das circunstâncias específicas da causa, o que leva à identificação da norma de caráter geral a partir do caso concreto - ou seja, a ratio decidendi, que constitui seu elemento nuclear. A jurisprudência, por sua vez, surge exatamente da reiteração de um precedente, enquanto a súmula é o enunciado normativo da ratio decidendi de uma jurisprudência dominante (Didier Jr. et al, 2015, p. 487). Note-se, ainda, que não basta a mera existência de alguns julgados em determinado sentido para que haja jurisprudência, mas a orientação reiterada, atual e prevalecente no âmbito de um tribunal (Redondo, 2014, pp.167-188).

Enquanto variados autores preocupam-se em traçar distinções entre esses três conceitos, o novo Código de Processo Civil já recebeu críticas pelo pouco cuidado técnico em seu emprego (Marinoni et al, 2015, p. 607). Para Luiz Guilherme Marinoni et al, isso é especialmente problemático em um contexto de 
ressignificação dos conceitos de jurisprudência e súmula ${ }^{16}$, bem como da introdução do conceito de precedente, no referido diploma (Marinoni et al, 2015, p. 610). De fato, o seu art. 927 inova ao estabelecer um rol de precedentes obrigatórios, que serão oportunamente analisados. Por ora, porém, basta dizer que Fredie Didier Jr. et al consideram-no não exaustivo, englobando, ainda, os precedentes cujo entendimento estiver consolidado nas súmulas de cada um dos tribunais - frise-se, ainda que não tribunais superiores ${ }^{17}$ (Didier Jr. et al, 2015, p. 461).

Daí a previsão do art. 926 do novo Código de Processo Civil, que impõe aos tribunais o dever de uniformizarem a sua jurisprudência, mantendo-a estável, íntegra e coerente. Esse dispositivo também será mais bem explorado adiante, mas vê-se, desde logo, que a edição de súmulas pelos tribunais depende eminentemente da existência de uma jurisprudência consolidada, assim como a formação desta depende da reiteração de precedentes. Não por outro motivo, o enunciado $n^{\circ} 169$ do Fórum Permanente de Processualistas Civis ${ }^{18}$ prevê que os órgãos do Poder Judiciário devem obrigatoriamente seguir os seus próprios precedentes (Didier Jr. et al, 2015, pp. 461-462). Dessa forma, embora esses precedentes não componham o rol do art. 927 do novo Código de Processo Civil e tampouco sejam, todos eles, raiz das súmulas emanadas pelos tribunais, decorre do próprio art. 926 a obrigação de segui-los - é o stare decisis.

Tais considerações, ainda que tenham adiantado, em parte, o detalhamento que se fará de cada um desses dispositivos, são relevantes na medida em que mostram que se pode falar em precedentes - e, por precedentes, opta-se por entendê-los necessariamente como obrigatórios, conforme visto no capítulo anterior - emanados também de outros órgãos que não os tribunais superiores. Luiz Guilherme Marinoni et al, por sua vez, são categóricos ao afirmarem que “os precedentes emanam exclusivamente das Cortes Supremas e são sempre

\footnotetext{
${ }^{16}$ Não cabe, no escopo deste trabalho, detalhar a ressignificação dos conceitos de jurisprudência e súmula. Em caso de interesse, cf. Marinoni et al, 2015, p. 610.

${ }^{17}$ As menções a tribunais superiores serão feitas sem o rigor técnico que o emprego da expressão exige, considerando inclusos no conjunto também eventuais tribunais supremos, como o Supremo Tribunal Federal.

${ }^{18}$ Trata-se de encontros periódicos de processualistas civis promovidos pelo Instituto Brasileiro de Direito Processual.
} 
obrigatórios - isto é, vinculantes" (Marinoni et al, 2015, p. 611). Trata-se de uma visão contraposta à que se busca defender no presente trabalho, que admite precedentes formados a partir de decisões judiciais nos demais órgãos do Poder Judiciário.

Ademais, Luiz Guilherme Marinoni et al consideram os mencionados dispositivos do novo Código de Processo Civil escorregadios e insuficientes para que se entenda o tratamento dos precedentes na ordem jurídica brasileira. Alegam, por exemplo, que o referido diploma imagina serem os precedentes apenas as hipóteses enumeradas no art. 927. Além disso, alegam que precedentes não são exclusivamente formais e quantitativos - como, para eles, parece sugerir o novo Código de Processo Civil -, mas materiais e qualitativos. Com isso, querem dizer que não basta a enumeração do art. 927, sendo necessário, ainda, que as hipóteses lá colocadas estejam de fato aptas a gerarem precedentes. Por exemplo, que tenham razões determinantes e suficientes claramente identificáveis (Marinoni et al, 2015, p. 611).

Com relação à primeira alegação, note-se que ela já foi afastada por Fredie Didier Jr. et al, ao dizerem ser o rol do art. 927 não exaustivo. Trata-se, segundo a visão aqui sustentada, de uma leitura mais condizente com os demais dispositivos do novo Código de Processo Civil, em particular o seu art. 926, bem como com o fortalecimento do papel dos precedentes que ele pretende implementar. Com relação à segunda alegação, de fato não basta que as hipóteses estejam enumeradas no art. 927 para que estejam aptas a gerarem precedentes. Nesse sentido, há que se considerar a sua dimensão material e o seu aspecto qualitativo, como bem observam Luiz Guilherme Marinoni et al. Uma vez preenchidos os requisitos necessários, porém, lá estariam os precedentes enumerados pelo art. 927 - e os demais precedentes comportados por ele. Obrigatórios, sim, mas não necessariamente exclusivos dos tribunais superiores.

Por fim, cabe ressaltar que as considerações de Luiz Guilherme Marinoni et al com relação ao tema têm profunda relação com a sua concepção de que as Cortes Supremas - Supremo Tribunal Federal e Superior Tribunal de Justiça - e as Cortes de Justiça - Tribunais Regionais Federais e Tribunais de Justiça - 
desempenham funções claramente distintas no ordenamento jurídico brasileiro. Caberia às primeiras o dever de dar unidade ao direito mediante os seus precedentes e às segundas controlar a uniforme aplicação destes, ou seja, uniformizá-los. Assim, os autores partem do pressuposto de que o novo Código de Processo Civil usou o termo "tribunais" sem atentar para essa distinção, especialmente no art. 926, quando deveria tê-lo feito (Marinoni et al, 2015, pp. 607-609).

Dessa forma, com os precedentes emanando apenas dos tribunais superiores, caberia aos demais tribunais a sua uniformização e o fomento do debate a respeito das melhores opções interpretativas para desacordos inerentes à interpretação do direito - debate este que não deveria ser tolhido. Para Luiz Guilherme Marinoni et al, é sob esta ótica que o art. 926 deveria ser particularizado (Marinoni et al, 2015, p. 608). A linha deste trabalho, porém, se atém à escolha legislativa pelo uso genérico do termo "tribunais". O claro propósito do novo Código de Processo Civil de fortalecimento do papel dos precedentes exigiria, ainda que em prejuízo da dinâmica institucional almejada por esses autores, que o dever incumbido aos tribunais de uniformizarem sua jurisprudência partisse não só dos precedentes emanados pelos tribunais superiores, mas também por eles próprios.

\section{III.II Principais dispositivos legais pertinentes}

Entendidas essas questões conceituais, cabe analisar mais detalhadamente os principais dispositivos do novo Código de Processo Civil relativos aos precedentes. Ressalve-se, entretanto, que não se pretende esgotar a análise do

referido diploma no que tange ao tema, importando mais a apresentação do panorama geral por ele inaugurado, de forma a destacar os desafios a serem enfrentados pela introdução de conceitos antes estranhos ao civil law, notadamente no direito brasileiro. Além disso, novamente ressalte-se - ainda que sob o risco de incorrer em desnecessária repetição - que, diferentemente de Patrícia Mello e Fredie Didier Jr. et al, a utilização do termo precedentes, aqui, já implica a sua obrigatoriedade. 


\section{(a) Art. 927 do novo Código de Processo Civil}

De início, é preciso tratar mais detalhadamente do art. 927 :

Art. 927. Os juízes e os tribunais observarão:

I - as decisões do Supremo Tribunal Federal em controle concentrado de constitucionalidade;

II - os enunciados de súmula vinculante;

III - os acórdãos em incidente de assunção de competência ou de resolução de demandas repetitivas e em julgamento de recursos extraordinário e especial repetitivos;

IV - os enunciados das súmulas do Supremo Tribunal Federal em matéria constitucional e do Superior Tribunal de Justiça em matéria infraconstitucional;

V - a orientação do plenário ou do órgão especial aos quais estiverem vinculados.

$\S 1^{\circ}$ Os juízes e os tribunais observarão o disposto no art. 10 e no art. $489, \S 1^{\circ}$, quando decidirem com fundamento neste artigo.

$\S 2^{\underline{0}} \mathrm{~A}$ alteração de tese jurídica adotada em enunciado de súmula ou em julgamento de casos repetitivos poderá ser precedida de audiências públicas e da participação de pessoas, órgãos ou entidades que possam contribuir para a rediscussão da tese.

$\S 3^{0} \mathrm{Na}$ hipótese de alteração de jurisprudência dominante do Supremo Tribunal Federal e dos tribunais superiores ou daquela oriunda de julgamento de casos repetitivos, pode haver modulação dos efeitos da alteração no interesse social e no da segurança jurídica.

$\S 4^{\circ}$ A modificação de enunciado de súmula, de jurisprudência pacificada ou de tese adotada em julgamento de casos repetitivos observará a necessidade de fundamentação adequada e específica, considerando os princípios da segurança jurídica, da proteção da confiança e da isonomia.

$\S 5^{\circ}$ Os tribunais darão publicidade a seus precedentes, organizando-os por questão jurídica decidida e divulgando-os, preferencialmente, na rede mundial de computadores. ${ }^{19}$

Trata-se, segundo o entendimento já apresentado de Fredie Didier Jr. et al, de um dispositivo não exaustivo. Os precedentes contidos em seu rol diferenciam-se entre si pelo seu procedimento de formação, podendo ser, por exemplo, um precedente em processo de controle concentrado de constitucionalidade, um simples incidente em julgamento de tribunal ou um procedimento de produção de enunciado de súmula (Didier Jr. et al, 2015, p. 461).

O inciso I do referido dispositivo prevê a observância obrigatória dos precedentes do Supremo Tribunal Federal produzidos em processo de controle concentrado de constitucionalidade. É preciso atentar para o fato de que os

\footnotetext{
${ }^{19}$ Texto extraído do novo Código de Processo Civil, disponível para consulta em http://www.planalto.gov.br/ccivil_03/_Ato2015-2018/2015/Lei/L13105.htm, acessado em 31 de maio de 2015.
} 
efeitos vinculantes dos precedentes e da coisa julgada erga omnes não se confundem (Didier Jr. et al, 2015, p. 464). A compreensão da distinção entre eles remonta à mencionada criação de duas normas jurídicas a partir de uma decisão judicial (Didier Jr. et al, 2015, p. 443): a norma de caráter geral correlaciona-se aos efeitos vinculantes dos precedentes, enquanto a norma de caráter individual correlaciona-se aos efeitos vinculantes da coisa julgada erga omnes. Cuidando disso, destacam Fredie Didier et al que o inciso I se refere à força obrigatória dos precedentes do Supremo Tribunal Federal produzidos em processo de controle de constitucionalidade, não à exigência de respeito à coisa julgada produzida nesses processos, até porque, para esses autores, não faria sentido uma previsão como essa. Isso porque todos já têm que respeitar a coisa julgada, sobretudo quando erga omnes, além do fato de que, como parecem indicar os incisos seguintes, trata-se de um rol de precedentes obrigatórios e não de hipóteses de formação de coisa julgada. Nesse sentido, diz o enunciado $n^{\circ} 168$ do Fórum Permanente de Processualistas Civis que são os fundamentos determinantes - ou seja, a ratio decidendi - do julgamento de ação de controle concentrado de constitucionalidade que produzem o efeito vinculante de precedente para todos os órgãos jurisdicionais (Didier Jr. et al, 2015, p. 464) ${ }^{20}$.

O inciso II reafirma a observância obrigatória dos enunciados de súmula vinculante em matéria constitucional, editados pelo Supremo Tribunal Federal na forma do art. 103-A da Constituição de 1988 e da Lei no 11.417/2006. Elas têm eficácia vinculante em relação ao próprio STF, a todos os demais órgãos jurisdicionais do país e à administração pública direta e indireta, nas esferas federal, estadual e municipal (Didier Jr. et al, 2015, p. 465).

O inciso III prevê a observância obrigatória de acórdãos em incidente de assunção de competência ou de resolução de demandas repetitivas e em julgamento de recursos extraordinário e especial repetitivos. Nesses casos, há

\footnotetext{
${ }^{20}$ Para os interessados pelo tema, note-se que a previsão dos efeitos vinculantes dos precedentes do art. 927, I do novo Código de Processo Civil é pertinente à controvérsia sobre a aplicabilidade ou não da teoria da transcendência dos motivos determinantes pelo Supremo Tribunal Federal. A saída parece estar justamente nos efeitos vinculantes dos precedentes e não nos efeitos vinculantes da coisa julgada erga omnes.
} 
previsão de incidente processual para elaboração do precedente obrigatório. Fredie Didier Jr. et al entende esses casos como uma espécie de formação concentrada de precedentes - havendo também, naturalmente, a formação difusa. Para eles, surgiria, assim, um microssistema de formação concentrada de precedentes obrigatórios, cujas regras se complementariam reciprocamente. Ressaltam os autores que o novo Código de Processo Civil amplia o contraditório nessas hipóteses, fazendo-o através de audiências públicas e da possibilidade de participação de amicus curiae, conforme os arts. 138, 927, § $2^{\circ}, 983$ e 1038, I e II (Didier Jr. et al, 2015, pp. 465-466).

O inciso IV prevê a observância obrigatória dos enunciados das súmulas do Supremo Tribunal Federal em matéria constitucional e do Superior Tribunal de Justiça em matéria infraconstitucional. Nisso, vai além do inciso II, justamente por abranger outras súmulas emanadas dos tribunais superiores que não as súmulas vinculantes (Didier Jr. et al, 2015, p. 465). Até então, somente os enunciados destas dispunham do que Patrícia Mello chama de eficácia normativa. Os das demais súmulas dispunham de eficácias mais fracas e, exatamente por isso, sob a ótica aqui adotada, sequer funcionavam como precedentes, mas como algo a ser sopesado - ainda que significativamente - pelos julgadores. O novo Código de Processo Civil, ao torná-los de observância obrigatória, aproximou-os das súmulas vinculantes (Didier Jr. et al, 2015, p. 465). Observe-se, entretanto, que não os igualou a elas, vez que as súmulas vinculantes, a uma, vinculam também a administração pública direta e indireta; a outra, precisam atender a pressupostos específicos enumerados no texto constitucional e reproduzidos pela Lei $\mathrm{n}^{\circ} 11.417 / 2006$ (Junqueira, 2012, p. 211).

O inciso $\mathrm{V}$ prevê a observância obrigatória da orientação do plenário ou do órgão especial aos quais estiverem vinculados. Para Fredie Didier Jr. et al, aí há, como em todos os precedentes de que trata o art. 927, duas ordens de vinculação: uma interna, dos membros e órgãos fracionários de um tribunal aos precedentes oriundos do seu plenário ou órgão especial; e uma externa, dos demais órgãos de instância inferior - juízos e tribunais - aos precedentes do plenário ou órgão especial do tribunal a que estiverem submetidos. Afinal, o 
precedente não deve vincular só o tribunal que o produziu, como também os órgãos a eles subordinados (Didier Jr., 2015, p. 466). Nesse sentido, o enunciado no 170 do Fórum Permanente de Processualistas Civis: "As decisões e precedentes previstos nos incisos do caput do art. 927 são vinculantes aos órgãos jurisdicionais a eles submetidos".

Por isso, defendem os autores que os precedentes do plenário do Supremo Tribunal Federal sobre matéria constitucional vinculam todos os tribunais e juízes brasileiros; os do plenário e órgão especial do Superior Tribunal de Justiça sobre matéria de direito federal infraconstitucional vinculam o próprio Superior Tribunal de Justiça, bem como Tribunais Regionais Federais, Tribunais de Justiças e juízes federais e estaduais a ele vinculados - nesse sentido, inclusive, o enunciado no 314 do Fórum Permanente de Processualistas Civis: "As decisões judiciais devem respeitar os precedentes do Supremo Tribunal Federal, em matéria constitucional, e do Superior Tribunal de Justiça, em matéria infraconstitucional federal" -; os do plenário e órgão especial dos Tribunais Regionais Federais vinculam os próprios Tribunais Regionais Federais, bem como juízes federais a eles vinculados; e os do plenário e órgão especial dos Tribunais de Justiça vinculam os próprios Tribunais de Justiça, bem como juízes estaduais a eles vinculados (Didier Jr., 2015, p. 467).

A previsão do inciso $\mathrm{V}$ de observância obrigatória da orientação do plenário ou do órgão especial é interessante também quando considerada no âmbito da cláusula de reserva de plenário. Fábio Leite, em obra publicada antes da sanção do novo Código de Processo Civil, defendia que a cláusula de reserva de plenário devesse ser entendida não como uma restrição imposta aos órgãos fracionários do tribunal, mas como uma liberação da submissão da arguição de inconstitucionalidade ao pleno ou ao órgão especial (Leite, 2011, p. 229). À luz desse novo dispositivo, há que se questionar se os órgãos fracionários estariam obrigados a seguir o entendimento do plenário ou do órgão especial inclusive nesse âmbito. 
Antes, entendia-se que o julgador só deveria parar para avaliar se era obrigado ou não a submeter a questão ao plenário ou ao órgão especial quando entendia pela inconstitucionalidade de determinado dispositivo, apoiando-se na presunção de constitucionalidade das leis para prosseguir normalmente quando entendesse pela sua constitucionalidade. Agora, em face do novo Código de Processo Civil, como ficaria a situação do julgador que, embora convencido da constitucionalidade de determinado dispositivo, se visse confrontado com um precedente do plenário ou do órgão especial a que estiver vinculado no sentido de sua inconstitucionalidade? Poderia prosseguir à decisão judicial quanto à demanda principal do caso ou estaria obrigado a adotar o entendimento da inconstitucionalidade do dispositivo em questão?

Como se vê, trata-se de questão importantíssima. Entender pela vinculação do julgador ao entendimento do plenário ou do órgão especial nessas circunstâncias equivaleria a admitir que as decisões judiciais tomadas por eles em âmbito de controle difuso de constitucionalidade teriam, por si só, o condão de abalar significativamente a presunção de constitucionalidade das leis para além da demanda a que dissessem respeito. Mais problemática ainda essa visão se confrontada com o art. 52, X da Constituição de 1988, que confere ao Senado Federal a atribuição de suspender a execução de leis declaradas inconstitucionais por decisão definitiva do Supremo Tribunal Federal. Este trabalho não pretende adentrar o mérito desse debate, satisfazendo-se em apontar o surgimento dessa problemática. Dessa forma, destaca-se o ponto de que as mudanças empreendidas pelo novo Código de Processo Civil com relação aos precedentes, embora pontualmente inseridas em seu texto, irradiam consequências por todo $\mathrm{o}$ ordenamento jurídico brasileiro.

Também com relação a alguns dos incisos do art. 927, notadamente os incisos III, IV e V, cabem algumas considerações extras: já foram eles alvo de pesadas críticas por parte de Nelson Nery Jr. et al (Nery Jr et al, 2015, p. 1156). Para esses autores, trata-se de dispositivos inconstitucionais, dado inexistir autorização expressa da Constituição de 1988 para as vinculações por eles estabelecidas. Argumentam que, para que o enunciado de súmula do Supremo 
Tribunal Federal pudesse vincular juízes e tribunais, foi necessária a edição de emenda constitucional, nela incluindo o art. 103-A. Seria necessário que se fizesse isso para autorizar o Poder Judiciário a legislar, já que a jurisprudência não teria força normativa maior do que a da própria Constituição de 1988 ou da lei. Os incisos I e II escaparam incólumes por entenderem os autores haver expressa autorização constitucional para tanto, mediante os arts. $102, \S 2^{\circ}$ e 103 A, caput.

Embora se considere importante anotar a existência de críticas como essa, o presente trabalho não se propõe a desconstruí-las. Satisfaz-se em registrar que a necessidade de emenda constitucional para introduzir no direito brasileiro a figura da súmula vinculante pode, também, ter se justificado em grande parte pela vinculação da administração pública direta e indireta ao Poder Judiciário problema este inexistente no art. 927 -, o que potencialmente interferiria na separação de poderes. Registra, ainda, que as normas jurídicas são, em si mesmas, fruto da interpretação conferida aos textos legais pelo Poder Judiciário, de forma que seria nebulosa qualquer linha que pretendesse separar os casos em que ele estivesse supostamente legislando daqueles em que não estivesse. De qualquer forma, até o momento, presume-se o art. 927 constitucional.

\section{(b) Art. 926 do novo Código de Processo Civil}

Também é pertinente a análise do art. 926:

Art. 926. Os tribunais devem uniformizar sua jurisprudência e mantê-la estável, íntegra e coerente.

$\S 1^{\circ} \mathrm{Na}$ forma estabelecida e segundo os pressupostos fixados no regimento interno, os tribunais editarão enunciados de súmula correspondentes a sua jurisprudência dominante.

$\S 2^{\underline{0}}$ Ao editar enunciados de súmula, os tribunais devem ater-se às circunstâncias fáticas dos precedentes que motivaram sua criação. ${ }^{21}$

Conforme já ressaltado, uma das decorrências mais importantes desse dispositivo é o entendimento de que, para que os tribunais possam consolidar sua jurisprudência dominante por meio da edição de súmulas, é necessário,

${ }^{21}$ Texto extraído do novo Código de Processo Civil, disponível para consulta em http://www.planalto.gov.br/ccivil_03/_Ato2015-2018/2015/Lei/L13105.htm, acessado em 31 de maio de 2015. 
primeiramente, que eles respeitem seus próprios precedentes. Caso contrário, não seria possível cumprir o dever previsto em seu caput. Nas palavras de Fredie Didier Jr. et al:

"Antes mesmo de produzir e seguir a sua súmula, os tribunais devem seguir seus próprios precedentes, para que haja sólida jurisprudência a ser sumulada. Esse dever é um dos conteúdos dos deveres gerais de integridade e coerência. Na verdade, 'sempre que um juiz ou tribunal for se afastar de seu próprio precedente, este deve ser levado com consideração, de modo que a questão do afastamento do precedente judicial seja expressamente tematizada' - não se pode admitir overruling implícito, como se verá adiante.” (Didier Jr. et al, 2015, p. 462)

Note-se que se fala de um dever de os tribunais seguirem seus próprios precedentes - ou seja, os precedentes têm força obrigatória em relação ao próprio tribunal que os proferiu e aos juízes a ele vinculados, ainda que eventualmente se admita a possibilidade de revisão de seu entendimento, desde que isso seja expressamente tematizado. Conforme trabalhado no capítulo anterior, para alguns autores, isso já seria o suficiente para retirar deles o condão da obrigatoriedade, trabalhando-se com a ideia de que eles apenas imporiam aos julgadores um ônus maior para seu afastamento. Já para Frederick Schauer, cuja visão vem sendo adotada, eles seguiriam sendo obrigatórios, ainda que não de forma absoluta e sim relativa - e apenas por isso, inclusive, poderiam ser considerados precedentes. Ressalte-se que o já citado enunciado no 169 do Fórum Permanente de Processualistas Civis, que trata do tema, também usa a palavra "obrigatoriamente".

Atente-se para o fato de que, no cenário anterior ao novo Código de Processo Civil, não se falava na obrigatoriedade do entendimento dos julgados de um tribunal em relação a ele próprio. Os operadores do direito bem sabem que, frequentemente, tal entendimento sequer chegava a persuadir os julgadores, quanto mais a impor-lhes qualquer ônus argumentativo para não aplicá-lo. Era comum que acabassem sendo tomados - pelas partes e pelos julgadores - por mera formalidade das peças processuais. Daí a importância de os tribunais estarem obrigados a seguir o entendimento de seus próprios julgados, precisando de fato enfrentar o seu afastamento. Por tudo isso, a introdução do stare decisis no direito brasileiro é, sem dúvida, uma das mais importantes alterações promovidas pelo novo Código de Processo Civil. 
O art. 926, embora sucinto, impõe aos tribunais mais que o simples dever de que sigam - eles e os juízes a eles vinculados - seus próprios precedentes. Ele preconiza alguns deveres gerais no âmbito da construção e manutenção de um sistema de precedentes: o dever de uniformizar sua jurisprudência; o dever de manter essa jurisprudência estável; o dever de integridade; o dever de coerência; e o dever de dar publicidade adequada aos seus precedentes (Didier Jr. et al, 2015, p. 473). Esses deveres servem como instrumentos para o desenvolvimento do microssistema de formação, aplicação e revogação de precedentes brasileiro é pela concretização do seu conteúdo normativo que será possível construir e compreender tal microssistema (Didier Jr. et al, 2015, pp. 476-477).

O dever de uniformização da jurisprudência preconiza que o tribunal não pode se omitir diante de divergência interna, entre seus órgãos fracionários, sobre a mesma questão jurídica. $\mathrm{O} \S 1^{\circ}$ e o $\$ 2^{\circ}$ do art. 926 têm profunda relação com isso: o primeiro desdobra o dever de uniformizar, dele extraindo o dever dos tribunais de sintetizarem sua jurisprudência dominante em súmulas; o segundo explicita que, ao fazê-lo, o tribunal deve ater-se à base fática a partir da qual elas foram construídas. Tal cuidado está associado à preservação do caráter de concretude do direito judicial que se constrói, conforme bem observam Fredie Didier Jr. et al (Didier Jr. et al, 2015, p. 474).

O dever de manter a jurisprudência estável relaciona-se, a um só tempo, à necessidade de que se justifique adequadamente qualquer mudança de posicionamento e à de que se module sua eficácia em respeito à segurança jurídica. Sobre isso, o enunciado n 316 do Fórum Permanente de Processualistas Civis: "a estabilidade da jurisprudência do tribunal depende também da observância de seus próprios precedentes, inclusive por seus órgãos fracionários." Esse dever se consubstancia no princípio da inércia $\operatorname{argumentativa~}^{22}$, que se desdobra em duas faces: pela primeira, eleva o ônus

\footnotetext{
${ }^{22}$ Fredie Didier Jr. et al destacam, no trecho abaixo referenciado, que o princípio da inércia argumentativa funda-se, além da legislação infraconstitucional, também na Constituição de 1988: na igualdade de tratamento para casos afins (art. $5^{\circ}$, caput); na motivação adequada tanto para a decisão que aplica como para aquela que afasta o precedente (art. 93, IX); e no contraditório, que pressupõe o dever de conhecer essa motivação para questioná-la por meios de impugnação cabí veis (art. 5º LV).
} 
argumentativo de quem se propõe a afastar um precedente - ou pela sua distinção do caso concreto, ou pela sua superação, conforme se verá adiante -; pela segunda, reduz o ônus argumentativo de quem se vale de um precedente para fundamentar uma decisão judicial, ainda que seja necessário identificar seus fundamentos determinantes e demonstrar a adequação do caso concreto a eles. Em razão da inércia argumentativa, preserva-se o status quo até que surjam razões extras antes não cogitadas ou enfrentadas (Didier Jr. et al, 2015, pp. 474475).

O dever de dar publicidade aos precedentes funda-se na ideia de que, a fim de que um sistema de precedentes tenha efetividade, é preciso que eles sejam amplamente divulgados - e, acrescente-se, de forma organizada. Não seria razoável esperar que operadores do direito tomassem conhecimento de todos os precedentes produzidos no âmbito dos tribunais pertinentes às suas causas pesquisando-os por conta própria. Uma vez que se entendem os precedentes como detentores de força jurídica inerente a eles, fica evidente que não basta tornar-lhes públicos. Não por outra razão, esse dever encontra amparo também em outros dispositivos do novo Código de Processo Civil: o art. 927, §5 prevê que caberá aos tribunais organizar seus precedentes por tema - mais especificamente, por questão jurídica decidida - e divulgá-los, de preferência, na rede mundial de computadores; e o art. 979 também consagra essa exigência, embora no âmbito do julgamento de casos repetitivos (Didier Jr. et al, 2015, pp. 475-476).

Os deveres gerais mais polêmicos do art. 926 são os deveres de coerência e de integridade - além de inédito, são de difícil compreensão. Isso se deve, em parte, ao fato de esses termos serem bastante utilizados em estudos contemporâneos sobre a teoria do direito e da decisão judicial, conforme apontam Fredie Didier Jr. et al. Ressaltam os autores, porém, que não há necessidade de o conteúdo normativo do texto corresponder exatamente a qualquer orientação filosófica.

Sob essa ótica, e prezando pela máxima efetividade do conteúdo normativo do texto, há que se pensar que o legislador criou dois deveres 
distintos, ainda que seja bem difícil entender um sem o outro e que frequentemente eles imponham, juntos, uma só conduta ao tribunal e aos juízes a ele vinculados. À soma dos deveres de coerência e integridade pode-se dar o nome de consistência - é ao fim de que se produza jurisprudência consistente que eles servem. Sustentam os autores, portanto, ser possível uma jurisprudência coerente, mas inconsistente, bem como íntegra, mas inconsistente. Para que se possa considerá-la tanto coerente quanto íntegra, é preciso que ela esteja lastreada em precedentes bem fundamentados, conforme se afere do art. $927, \S^{\circ}$ e do art. 489, $\S 1^{\circ}$, ainda a ser analisado. Assim, mais que meros deveres, coerência e integridade são postulados hermenêuticos, pressupostos para a possibilidade de universalização da jurisprudência - sua legítima aplicação a outros casos semelhantes -, sem a qual não se pode falar em um sistema de precedentes racional e não autoritário (Didier Jr. et al, 2015, p. 479) ${ }^{23}$.

\section{(c) Art. 489 do novo Código de Processo Civil}

Embora interessantes considerações possam ser tecidas em relação ao caput e a cada um dos três parágrafos desse dispositivo - todos, em alguma medida, pertinentes ao tema da fundamentação das decisões judiciais -, este tópico tomará como foco o seu $\S 1^{\circ}$, responsável por enumerar as hipóteses em que não se considera fundamentada uma decisão judicial. Com isso, atém-se à pretensão do presente trabalho de demonstrar que a introdução do conceito de precedente no processo civil exige mudanças significativas na forma com que tradicionalmente se operava o direito brasileiro. Talvez por isso tenha $\mathrm{o}$ legislador se preocupado em expurgar, já de antemão, possíveis dúvidas quanto ao que seria considerado suficiente ou não para fundamentar adequadamente uma decisão judicial. Ao texto legal:

\footnotetext{
${ }^{23}$ Fredie Didier Jr. et al, na obra acima referenciada, analisam minuciosamente os deveres de integridade e coerência. Preocupam-se, inclusive, em traçar as distinções necessárias à conclusão de que se trata, realmente, de dois deveres distintos. Tais considerações não foram incluídas porque, para a o apanhado dos deveres gerais a que se pretende o presente trabalho, basta a análise da consistência e a sua relação com a fundamentação dos precedentes.
} 
Art. 489. São elementos essenciais da sentença:

I - o relatório, que conterá os nomes das partes, a identificação do caso, com a suma do pedido e da contestação, e o registro das principais ocorrências havidas no andamento do processo;

II - os fundamentos, em que o juiz analisará as questões de fato e de direito;

III - o dispositivo, em que o juiz resolverá as questões principais que as partes lhe submeterem.

$\S 1^{\underline{0}}$ Não se considera fundamentada qualquer decisão judicial, seja ela interlocutória, sentença ou acórdão, que:

I - se limitar à indicação, à reprodução ou à paráfrase de ato normativo, sem explicar sua relação com a causa ou a questão decidida;

II - empregar conceitos jurídicos indeterminados, sem explicar o motivo concreto de sua incidência no caso;

III - invocar motivos que se prestariam a justificar qualquer outra decisão;

IV - não enfrentar todos os argumentos deduzidos no processo capazes de, em tese, infirmar a conclusão adotada pelo julgador;

$\mathrm{V}$ - se limitar a invocar precedente ou enunciado de súmula, sem identificar seus fundamentos determinantes nem demonstrar que o caso sob julgamento se ajusta àqueles fundamentos;

VI - deixar de seguir enunciado de súmula, jurisprudência ou precedente invocado pela parte, sem demonstrar a existência de distinção no caso em julgamento ou a superação do entendimento.

$\S 2^{-}$No caso de colisão entre normas, o juiz deve justificar o objeto e os critérios gerais da ponderação efetuada, enunciando as razões que autorizam a interferência na norma afastada e as premissas fáticas que fundamentam a conclusão.

$\S 3^{\circ}$ A decisão judicial deve ser interpretada a partir da conjugação de todos os seus elementos e em conformidade com o princípio da boa-fé. ${ }^{24}$

O rol contido no $\$ 1^{\circ}$ é exemplificativo, na medida em que visam concretizar o direito fundamental à motivação das decisões judiciais do art. 93, IX, CF (Didier Jr. et al, 2015, p. 327). Note-se que os incisos I, II, III e IV traduzem uma preocupação argumentativa necessária a qualquer sistema que pretenda utilizar-se de precedentes. Afinal, as condutas neles enumeradas dificultariam a identificação da ratio decidendi de qualquer decisão judicial, inviabilizando, assim, o seu funcionamento como precedente com relação aos casos análogos futuros.

$\mathrm{O}$ inciso $\mathrm{V}$, por sua vez, também remete a um cuidado com o funcionamento dos precedentes: a aplicação de precedentes aos casos análogos futuros não pode ser feita descriteriosamente, sob pena de levar ao colapso do próprio sistema que a prevê. Daí, inclusive, a importância dos incisos anteriores. São eles os responsáveis por fazer com que se esclareça qual é a tese jurídica

${ }^{24}$ Texto extraído do novo Código de Processo Civil, disponível para consulta em http://www.planalto.gov.br/ccivil_03/_Ato2015-2018/2015/Lei/L13105.htm, acessado em 31 de maio de 2015. 
projetada pela decisão judicial, bem como qual é a estrutura fática adequada à aplicação dessa mesma tese jurídica. Constroem-se, pois, duas faces da mesma moeda: toda decisão judicial tem que se preocupar em fornecer as informações necessárias à aplicação do precedente por ela estabelecido; e toda decisão judicial que de fato o aplique tem que se preocupar em identificar exatamente os seus fundamentos determinantes e a estrutura fática que permitiu tal aplicação, de forma a justificá-la.

O inciso VI remonta às formas de não aplicação de precedentes estudadas no capítulo anterior. O cerne da sua previsão é que a obrigatoriedade dos precedentes se impõe nas situações em que eles forem aplicáveis. E, contrario sensu, não há que se falar que foi desrespeitada tal obrigatoriedade quando da não aplicação dos precedentes nos casos em que eles já não fossem aplicáveis. Assim, o inciso VI é responsável por chamar atenção para esse aspecto, normatizando os mecanismos do distinguishing e do overruling. $\mathrm{O}$ primeiro justificando a não aplicabilidade de determinado precedente por diferenciar a sua estrutura fática daquela do caso em tela, notadamente em algum ponto necessário à aplicação da própria tese jurídica do precedente. O segundo justificando a sua não aplicação pela demonstração de sua superação - quando se tratar do que Frederick Schauer chama de precedente vertical -, ou pelo entendimento de que ele não mais é adequado - quando se tratar de precedente horizontal -, ressalvando-se a necessidade de que isso se dê em caráter excepcionalíssimo e por motivo suficientemente forte, sob pena de que o precedente deixe de agir como um precedente para tornar-se apenas mais um argumento a ser considerado, como já notou Frederick Schauer no capítulo anterior. Ressalta o inciso VI, ainda, a necessidade de enfrentar a questão na hipótese de aplicação de qualquer desses mecanismos, não se admitindo que isso seja feito de forma implícita (Didier Jr. et al, 2015, p. 494).

Também é essencial perceber que Fredie Didier Jr. et al destacam ser o inciso VI aplicável somente ao que chamam de precedentes obrigatórios, vez que, no caso dos que eles entendem como precedentes persuasivos, o julgador teria liberdade para simplesmente não concordar com a tese jurídica contida no 
precedente, ainda que a sua estrutura fática fosse equiparável à do caso em tela. Para Frederick Schauer, claro, bastaria dizer que tal inciso se aplica somente aos precedentes. Em face das já mencionadas críticas ao pouco cuidado técnico do novo Código de Processo Civil, entretanto, de fato parece pertinente o esclarecimento de Fredie Didier Jr.: exemplos de aplicação do inciso VI seriam as hipóteses do art. 927, o art. 932, IV e V e o art. 332. Não se pode dizer o mesmo do inciso V, vez que o julgador pode invocar tanto o que Fredie Didier Jr. et al chamam de precedentes obrigatórios - ou, aqui, simplesmente precedentes quanto precedentes persuasivos - ou julgados persuasivos. Em ambos os casos, porém, para que eles de fato fundamentem a decisão judicial, será preciso demonstrar sua aplicabilidade ao caso em tela (Didier Jr. et al, 2015, p. 341).

Por fim, note-se que a ausência de fundamentação é causa tão-somente de nulidade da decisão judicial, enquanto a ausência de dispositivo é causa de sua inexistência. Essa distinção reflete a existência das duas normas jurídicas produzidas pela decisão judicial: a de caráter individual, necessária para efetivamente se chegue a uma solução da questão discutida; e a de caráter geral, necessária para que tal solução não seja viciada. Trata-se, portanto, de um duplo conteúdo mínimo de qualquer decisão judicial, sendo a fundamentação necessária para validá-la e para projetar no ordenamento jurídico seu precedente - dado ser nela, geralmente, que se encontra a ratio decidendi (Didier Jr. et al, 2015, pp. 443-444).

\section{III.III O stare decisis como regra}

Como se pôde ver a partir dessa breve exposição sobre as mudanças promovidas pelo novo Código de Processo Civil no que tange aos precedentes, o papel a eles atribuído no direito brasileiro passa a ser significativamente mais robusto. Por isso, inclusive, não se contentou o referido diploma em lançar mão do conceito de precedentes, presumindo as implicações decorrentes do seu funcionamento. Ele foi além, normatizando muitas dessas implicações em seus próprios dispositivos, do que é exemplo claro o art. $489, \S 1^{\circ}$. 
Apesar da robustez desse novo papel - ou talvez até mesmo em função dela -, Fredie Didier Jr. et al consideram necessário destacar o que, para eles, já era óbvio: nem todas as decisões judiciais formam precedentes vinculantes (Didier Jr. et al, 2015, p. 463). Trata-se de entendimento cristalizado no enunciado no 315 do Fórum Permanente de Processualistas Civis. Quanto a esse ponto, cabe uma breve reflexão. Conforme já notado, bem observaram Luiz Guilherme Marinoni et al que os precedentes, mais que formais e quantitativos, são materiais e qualitativos, de forma que realmente não é toda decisão judicial que está apta a formar precedentes. É preciso, para tanto, que elas reúnam alguns elementos, já mencionados.

A despeito disso, é possível que não a essa dimensão - ou não apenas a ela - estivessem se referindo Fredie Didier Jr. et al, entendido que o conceito de precedente adotado em sua obra admite a atribuição de outras eficácias aos precedentes que não a obrigatória (Didier Jr. et al, 2015, pp. 453-461). Assim, poder-se-ia pensar que, mesmo que consideradas apenas decisões judiciais aptas a formarem precedentes, esses autores entendam que nem todos eles seriam de observância obrigatória - ou seja, nem todos vinculariam julgadores. De fato, isso parece ter sido demonstrado com relação à vinculação de um julgador aos precedentes de um órgão que lhe for superior. Nem todas as decisões judiciais de um órgão vinculam os julgadores daqueles órgãos que lhe forem inferiores. Já com relação à vinculação dos julgadores a seus próprios precedentes e aos do órgão a que estiverem vinculados ${ }^{25}$, cabe o questionamento quanto a essa afirmação.

A linha argumentativa aqui construída - e corroborada, diga-se de passagem, pelo já mencionado enunciado $\mathrm{n}^{\circ} 169$ do Fórum Permanente de Processualistas Civis - entende que decorre dos dispositivos analisados do novo Código de Processo Civil a observância obrigatória dos órgãos do Poder Judiciário a seus próprios precedentes. Assim, todas as decisões judiciais aptas a formar precedentes gerariam ao menos precedentes vinculantes com relação ao

\footnotetext{
${ }^{25}$ Observada a hierarquia interna desses órgãos, claro, de forma que um desembargador possa uniformizar divergências internas do tribunal a que pertencer.
} 
próprio órgão que os proferiu e aos julgadores a ele vinculados, ainda que não com relação a outros órgãos e julgadores. Naturalmente, essa ótica alinha-se à de Frederick Schauer e à de Luiz Guilherme Marinoni no sentido de entender que a possibilidade de overruling não faz com que um precedente necessariamente deixe de ser de observância obrigatória. Talvez nisso, inclusive, consista a aparente divergência agora construída com a constatação de Fredie Didier Jr. et al, visto ser possível, para eles, que a possibilidade de overruling já configure uma eficácia mais fraca que a obrigatória.

Vale a observação, entretanto, de que o presente trabalho entende que todos os precedentes já vinculam, ao menos, os julgadores que os proferiram e os órgãos a que estiverem vinculados, valendo o stare decisis em todas as decisões judiciais aptas a produzirem precedentes. Assim, o stare decisis como regra - e não como algo ocasional - seria uma das mais importantes inovações do novo Código de Processo Civil. 


\section{Conclusão}

O papel proeminente que os precedentes passarão a assumir no direito brasileiro a partir da entrada em vigor do novo Código de Processo Civil ressalta a importância da argumentação nas decisões judiciais. A sua normatividade torna imperativo que os julgadores fundamentem cuidadosamente suas decisões, uma vez que o entendimento preconizado pelos precedentes depende da identificação da ratio decidendi.

Sendo a argumentação alçada a essa função proeminente, outra questão vem à tona. Pontuou-se, no presente trabalho, que não raro os operadores do direito - aí incluídos julgadores e advogados - criam e valem-se da jurisprudência de forma arbitrária e descuidada. Demonstrouse, ainda, a importância que os precedentes estão prestes a assumir no direito brasileiro. Até aqui, trata-se de uma análise descritiva do que atualmente ocorre e do que se prevê que vá acontecer.

A partir desse cenário, cabem algumas considerações normativas. Levando em conta que muitas decisões judiciais não dedicam a devida atenção à fundamentação - mesmo que por motivos compreensíveis, como a sobrecarga do Poder Judiciário -, sendo frequente, por exemplo, que teses jurídicas sejam derrotadas sem serem adequadamente enfrentadas, é desejável que elas gerem precedentes? É desejável que os julgadores estejam vinculados às suas próprias decisões judiciais e, em determinados casos, àquelas dos órgãos que lhes forem superiores?

Este trabalho aposta que sim, especialmente porque o novo Código de Processo Civil não se preocupa apenas com o fortalecimento do papel dos precedentes, mas também com a fundamentação cuidadosa das decisões judiciais que eles exigem. Assim, embora se saiba que há muitos problemas a serem corrigidos na operação do direito brasileiro, já se vislumbra um caminho que deve ser percorrido para fazê-lo. E esse caminho parece passar, inevitavelmente, pelos precedentes. 


\section{Bibliografia}

BARBOZA, Estefânia M. de Q. Precedentes judiciais e segurança jurídica: fundamentos e possibilidades para a jurisdição constitucional brasileira. São Paulo: Saraiva, 2014. 304 p.

BARROSO, Luís Roberto. A verdade não tem dono: a ascensão do Judiciário e a indeterminação do direito no mundo contemporâneo. Publicado no veículo virtual Jota em 22 de setembro de 2014. Disponível em http://jota.info/academia/academia1-a-verdade-nao-tem-dono-a-ascensao-do-

judiciario-e-a-indeterminacao-do-direito-no-mundo, acessado em 25 de novembro de 2014.

DIDIER JR., Fredie; BRAGA, Paula Sarno; e DE OLIVEIRA, Rafael Alexandria. Curso de direito processual civil: teoria da prova, direito probatório, decisão, precedente, coisa julgada e tutela provisória. v. 2. 10. ed. Salvador: Jus Podivm, 2015. 674 p.

FERRERES, Víctor; e XIOL, Juan Antonio. El carácter vinculante de la jurisprudencia. 2. ed. Madrid: Fundación Coloquio Jurídico Europeo, 2010. 137 p.

JUNQUEIRA, Maria Olívia P. A construção da súmula vinculante pelo STF: impressões sobre as primeiras experiências. In: VOJVODIC, Adriana; PINTO, Henrique M.; GORZONI, Paula; e DE SOUZA, Rodrigo P. (Orgs.). Jurisdição constitucional do Brasil. São Paulo: Malheiros Editores, 2012. pp. 210-227.

LEITE, Fábio C. A cláusula de reserva de plenário segundo os tribunais de justiça. In: Direitos Fundamentais \& Justiça/Pontifícia Universidade Católica do Rio Grande do Sul. Programa de Pós-Graduação, Mestrado e Doutorado, n. 15, abr-jun. 2011. Porto Alegre: Editora, 2011. pp. 210-229. 
MARINONI, Luiz Guilherme. Precedentes obrigatórios. São Paulo: Revista dos Tribunais, 2010. $542 \mathrm{p}$. . A ética dos precedentes - justificativa do novo CPC. São Paulo: Revista dos Tribunais, 2014. 126 p.

MARINONI, Luiz Guilherme; ARENHART, Sérgio Cruz; e MITIDIERO, Daniel. Curso de processo civil: tutela dos direitos mediante procedimento comum. v. 2. São Paulo: Revista dos Tribunais, 2015. 1101 p.

MELlO, Patrícia P. C. Precedentes: o desenvolvimento judicial do direito no constitucionalismo contemporâneo. Rio de Janeiro: Renovar, 2008. 348 p.

NERY JR., Nelson; NERY, Rosa Maria de A. Comentários ao Código de Processo Civil: novo CPC - Lei 13.105/2015. São Paulo: Revista dos Tribunais, 2015. $2000 \mathrm{p}$.

REDONDO, Bruno Garcia. Precedente judicial no direito processual civil brasileiro. In: MENDES, Aluísio Gonçalves de Castro; MARINONI, Luiz Guilherme; WAMBIER, Teresa Arruda Alvim (coord.). Direito jurisprudencial: volume 2. São Paulo: Revista dos Tribunais, 2014. v. 2. pp. 167-188.

SCHAUER, Frederick. Thinking like a lawyer. HUP: 2009. Verificar a página na versão original. $239 \mathrm{p}$.

STRUCHINER, Noel. Para falar de regras: o positivismo conceitual como cenário para uma investigação filosófica acerca dos casos difíceis do direito. Rio de Janeiro. 2005. 191 p. Tese (Doutorado em Filosofia) - Departamento de Filosofia da PUC-Rio. 191 p. 